\title{
STRUGGLING FOR AIR: THE KYOTO PROTOCOL, CITIZENS' SUITS UNDER THE CLEAN AIR ACT, AND THE UNITED STATES' OPTIONS FOR ADDRESSING GLOBAL CLIMATE CHANGE
}

\author{
Richard W. Thackeray, Jr."
}

The chemical and thermal dynamics of global warming are extremely complex, but scientists are looking especially carefully at the role played by one molecule: carbon dioxide $\left(\mathrm{CO}_{2}\right)$. Since the beginning of the industrial revolution, we have been producing increasing quantities of $\mathrm{CO}_{2}$, and we are now dumping vast amounts of it into the global atmosphere ... Given the apparent close relationship between $\mathrm{CO}_{2}$ and temperatures in the past, it hardly seems reasonable —or even ethical - to assume that it is probably all right to keep driving up $\mathrm{CO}_{2}$ levels. In fact, it is almost certainly not all right. Isn't it reasonable to assume that this unnatural and rapid change in the makeup of a key factor in the environmental equilibrium could have sudden and disastrous effects? ${ }^{1}$

The greenhouse debate is short on facts and long on rhetoric. ... [It] poses a serious dilemma for policy makers. The experts are deadlocked on both the likelihood and the timing of the problem. Enormous uncertainties remain in our understanding of the greenhouse effect, its likely consequences, and the possible effectiveness of various countermeasures. These uncertainties will not be resolved for decades. ${ }^{2}$

Carbon dioxide makes up less than one-tenth of one percent $(0.03 \%)$ of the atmosphere and exists as a natural by-product of animal respiration and geothermal activity. ${ }^{3}$ Nevertheless, the gas's relationship to global climate

* J.D., 2004, Indiana University School of Law-Indianapolis; B.A. Political Science, 1995, University of Southern Maine. The author wishes to thank his wife, Carrie, for her support, patience, and ability to cope with his inability to keep the terms "Kyoto" or "carbon dioxide" out of dinner conversations. The author dedicates this note to his son, Noah Myles Thackeray, and to the hope that his generation can counter any consequences of this generation's inaction on the global warming problem.

1. SENATOR Al Gore, EARTH IN THE BaLANCE: ECOLOGY AND THE Human SPIRIT 92, 96 (1992).

2. AlAN S. MANNE \& RichaRD G. RICHELS, BuYING GREENHOUSE INSURANCE: THE ECONOMIC COSTS OF CARBON DIOXIDE EMISSION LIMITS 1 (1992).

3. Riehl, Herbert, "Air." Grolier Multimedia Encyclopedia. Scholastic Library Publishing 2004, available at http://gme.grolier.com (last visited Mar. 29, 2004). 
change has nurtured one of the most contentious debates in the fields of environmental science, environmental law, and international relations. ${ }^{4} \mathrm{On}$ December 11, 1997, 157 nations tentatively agreed to "the most far-reaching proposed international environmental treaty obligation in history, the Kyoto Protocol to the United Nations Framework Convention on Climate Change," (Protocol). 5

Protocol drafters called for a five percent reduction in greenhouse gas emissions ${ }^{6}$ in industrialized countries, based on their 1990 statistics, by $2012 .^{7}$ By the end of September 2003, 119 countries ratified, accepted, acceded to, or approved the treaty, including all fifteen members of the European Union, China, and Canada. ${ }^{8}$ The United States, under the administration of President Bill Clinton ${ }^{9}$, was among the countries that agreed in principle to the Kyoto Protocol. ${ }^{10}$ However, the U.S. Senate announced in two resolutions that it would not ratify the treaty as presented, and President George W. Bush said in March 2001, "As far as I'm concerned, the Kyoto Protocol is dead." 11

4. See generally ThOMAs GALE MOORE, Climate of FEAR: WhY We Shouldn'T WORRY ABOUT GLOBAL WARMING (1998); GORE, supra note 1.

5. Thomas Richichi, Although Storm Clouds Threatened Throughout the Global Warming Conference, in Kyoto, the Conferees Reached an Agreement on Greenhouse Gas Emissions, 20 NAT'L L. J., Dec. 29, 1997, at B4, col. 1. See also United Nations Framework Convention on Climate Change, May 29, 1992, U.N. Doc. A:AC.237/18 (1992), reprinted at 31 I.L.M. 849 (1992) [hereinafter Convention]. See also Kyoto Protocol to the United Nations Framework Convention on Climate Change, Dec. 10, 1997, U.N. Doc. FCC/CP/1997/L.7Add.1, reprinted at 37 I.L.M. 22 (1998) [hereinafter Protocol].

6. Carbon dioxide, combined with methane gas, represents about eighty-six percent of all the greenhouse gases being added to the atmosphere. See MOORE, supra note 4, at 10. (citing National Research Council, Policy Implications of Greenhouse Warming: Scientific Assessment (1991)). Chlorofluorocarbons and nitrous oxides are the other greenhouse gases which appear in the atmosphere in significant volumes. Id.

7. Id.

8. See Kyoto Protocol, Status of Ratification (last modified on Mar. 17, 2004), available at http://unfccc.int/resource/kpstats.pdf (last visited Mar. 29, 2004) [hereinafter Protocol Status]. See also Les Whittington, Chretien Ratifies Kyoto, TORONTO STAR, Dec. 17, 2002, at A6; Kurt Shillinger, Russia Backs Kyoto Treaty as Criticism of US Grows, BOSTON GLOBE, Sept. 4, 2002, at A6. Russian President Vladimir Putin recently balked after giving earlier indications he would ratify the treaty. See Susan B. Glasser, Russian Stance Leaves Fate of Global Warming Pact in Doubt, WASH. Post, Sept. 30, 2003, at A14. Attendees of September 2003's five-day U.N. World Climate Change Conference in Moscow expected Putin to announce his country's decision to ratify the treaty at his opening address to the conference. See id. Instead, the Russian leader told the assembly that "his government 'is closely studying' ratification but warned that it is "part of a complex of difficult and unclear problems." Id.

9. President Bill Clinton served from 1993-2001. See Sitkoff, Harvard, "Clinton, Bill." Grolier Multimedia Encyclopedia. Scholastic Library Publishing 2004, available at http://gme.grolier.com (last visited Mar. 30, 2004).

10. See Protocol Status, supra note 8.

11. Shillinger, supra note 8; see also Jeff Nesmith, Rejection of Kyoto Treaty On Climate May Leave U.S. Companies Out In Cold, ATLANTA JOURNAL-CONSTITUTION, July 27, 2002, at 8G. 
Despite the apparent lack of gravity the Bush administration and Congress assign to the carbon dioxide problem, some legal commentators believe the existing pollution control framework incorporated in the Clean Air $\mathrm{Act}^{12}$ provides a way to reduce carbon emissions without international commitments. ${ }^{13}$ One team of commentators noted, "The question of whether EPA has the authority to address the climate problem to any extent under the Clean Air Act should not be confused with the issue of implementing the terms of the Kyoto Protocol."14

Nonetheless, any mechanism the United States either elects to or is required to enact will likely bear some resemblance to the emissions reduction targets tied into the Kyoto Protocol. ${ }^{15}$ This Note focuses on the Environmental Protection Agency's (EPA) ability to regulate carbon dioxide as a criteria pollutant under the Clean Air Act, and the relationship of that ability to the United States' would-be commitments under the Kyoto Protocol. ${ }^{16}$ Part One provides a scientific background explaining the significance of atmospheric greenhouse gas volumes and their relationship to global warming. ${ }^{17}$ Part Two traces the evolution of the international community's understanding of greenhouse gases and provides an outline of the mechanisms it has established to counter global warming. ${ }^{18}$

Part Three of this Note explores the authority Congress vests in the EPA to mitigate the effects of air pollutants in the nation's airspace. Part Four views the process of adopting a "criteria" pollutant through the example of lead, as established by the United States Court of Appeals for the Second Circuit. ${ }^{19}$ Part Five analyzes the merits of carbon dioxide as a candidate for such regulation in light of two recent efforts by states to force the EPA's hand through the courts. Finally, Part Six compares the likely result of the EPA's forced regulation of carbon dioxide (either as a criteria pollutant or through motor vehicle emissions limits) with the emissions reduction limits assigned to the United States by the Kyoto Protocol. This Note suggests that any consent decree from the U.S. Court of Appeals for the D.C. Circuit will force the United States into at least partial de facto compliance with the Kyoto Protocol, an international treaty that President George W. Bush has declared "dead."

12. 42 U.S.C. $\$ \S 7401-7671 q$ (1995).

13. See Veronique Bugnion \& David M. Reiner, A Game of Climate Chicken: Can EPA Regulate Greenhouse Gases Before the U.S. Senate Ratifies the Kyoto Protocol?, 30 ENVT'L. L. $491,524 .(2000)$.

14. Id.

15. See generally id.

16. See generally id.

17. See generally id.

18. See generally id.

19. Natural Res. Def. Council, Inc. v. Train, 545 F.2d 320 (2d Cir. 1976).

20. See Shillinger, supra note 8. 


\section{THE GREenhouse EFFeCT AND Global Climate ChangE:}

\section{A SCIENTIFIC OVERVIEW}

The Earth's atmosphere is comprised of an amalgam of gases, including a class of gases which retain heat known as greenhouse gases. ${ }^{21}$ Greenhouse gases, while just a fragment of the Earth's total atmosphere, serve a vital role by "keep[ing] the Earth at a temperature that sustains life as we know it."22 The "Greenhouse Effect," or "infrared forcing," retains heat in the Earth's atmosphere by absorbing heat as it emanates from the Earth's surface and blocking its escape from the atmosphere. ${ }^{23}$ Climate history studies show that since the mid-1800s, the proportion of carbon dioxide, the most plentiful greenhouse gas (GHG) in the atmosphere "has risen as a result of human activities from about 270 parts per million (p.p.m.) to about 360 p.p.m. or about 30 percent above what it was ... and more than 20 percent above the highest concentration in 260,000 years." 24

The term "human activities" encompasses all human actions that release carbon dioxide into the atmosphere, but commentators who use the term largely do so as a synonym for emissions. ${ }^{25}$ Human activities caused about one-tenth of one billion metric tons of carbon emissions in $1860{ }^{26}$ That number rose to one and one-half billion metric tons by 1940, passed three billion metric tons by 1960 , and topped eight billion metric tons in the late 1980s. ${ }^{27}$ Between 1950 and 1980, "worldwide emissions of carbon dioxide increased 219 percent, or 7.3 percent a year." 28 Increases in carbon dioxide

21. See Bruce E. Johansen, The Global Warming Desk Reference 3 (2002). "The Earth's atmosphere is comprised of 78.1 percent nitrogen and 20.9 percent oxygen. All the other gases, including those responsible for the greenhouse effect, make up only about one percent of the atmosphere. Carbon dioxide $\left(\mathrm{CO}_{2}\right)$ is 0.035 percent; methane $\left(\mathrm{CH}_{4}\right)$ is 0.00017 percent, and ozone 0.000001-0.000004 percent." Id.

22. Id.

23. See id.

24. Id. at xiv (quoting Paul Epstein, et al., Current Effects: Global Climate Change. An Ozone Action Roundtable, June 24, 1996, Washington D.C., available at http://www.ozone. org/curreff.html). Scientists have extrapolated these figures from carbon dioxide concentrations observed in Antarctic ice cores, which froze between 260,000 and 420,000 years ago. See id.

25. See JOHANSEN, supra note 21 , at 3 . Human activities are also understood to include land use changes. See Stabilisation and Commitment to Future Climate Change, United Kingdom, Dept. for Environment Food and Rural Affairs 6 (Oct. 2002), available at http://www.meto.gov.uk/research/hadleycentre/pubs/brochures/B2002/global.pdf (last visited Oct. 27, 2003) [hereinafter Stabilisation].

26. See JOHANSEN, supra note 21 , at 3.

27. See id.

28. Id. Another report quantifies it this way: "Continuous high-precision measurements have been made of its atmospheric concentrations only since 1958, and by the year 2000 the concentrations have increased $17 \%$ from 315 [p.p.m.] . . to 370 [p.p.m.]." See Climate Change Science: An Analysis of Some Key Questions, National Research Council (1991), at 10, available at http://books.nap.edu/html/climatechange/climatechange.pdf (last visited Mar. 30, 2004) [hereinafter NRC Report]. 
emissions coincide with the era of global industrialization, which "[b]etween 1850 and 2000, [saw] human combustion of fossil fuels ... rise[] 50-fold."29

Not all emissions remain in the atmosphere, due to the interrelationship the atmosphere shares with oceans and the biosphere known as the carbon cycle. ${ }^{30}$ Forests, oceans, and biomass, collectively known as "carbon sinks," absorb carbon dioxide from the atmosphere and do so at increasing rates relative to the concentration of the gas in the air. ${ }^{31}$ However, the absorptive power of oceans, trees, and plantlife stabilizes once carbon dioxide emission levels surpass the rate at which it can be absorbed. ${ }^{32}$ Scientists estimate that the stabilization phenomenon will occur when carbon dioxide levels reach 550 p.p.m., which could occur within the next century. ${ }^{33}$

Some parts of the world have witnessed a decline in carbon emissions, but the expansion of fossil fuel-based industrial development to new regions has yielded an overall increase of global carbon emissions through the $1990 \mathrm{~s}^{34}$ The United States' carbon emissions rose from 2.86 billion tons in 1960 to 4.80 billion in $1988 .{ }^{35}$ Over the same period, China's carbon emissions leapt from 0.79 billion tons to 2.24 billion tons. ${ }^{36}$ While the United States' emissions more than doubled between 1950 and 1988, its percentage of global carbon emissions dropped from forty to twenty-two percent. ${ }^{37}$

Scientists generally agree about the science of the greenhouse effect and how human activities have exacerbated the phenomenon. ${ }^{38}$ The bulk of the skepticism about climate change science centers on the use of models to predict future climate change effects. ${ }^{39}$ However, a United Nations-chartered body of scientists has undertaken to improve the science in hope of predicting, and eventually preventing any adverse effects that global climate change

29. JOHANSEN, supra note 21 , at 3

30. See Stabilisation, supra note 25 , at 6 .

31. See id.

32. See id. For instance, "increases in $\mathrm{CO}_{2}$ lead to changes in temperature and rainfall, which can affect natural carbon sinks. Over land, climate change can alter the geographical distribution of vegetation and hence its ability to store $\mathrm{CO}_{2}$." Id. This pattern "results in a dying-back of the vegetation," "affects the amount of $\mathrm{CO}_{2}$ emitted by bacteria in the soil," and due to "changes in circulation and mixing, which accompany climate change, alter[s] the ocean's ability to take up $\mathrm{CO}_{2}$ from the atmosphere." Id. Finally, "warmer oceans absorb less $\mathrm{CO}_{2}$." Id.

33. See Stabilisation, supra note 25 , at 7.

34. See JOHANSEN, supra note 21 , at 7,8 .

35. See id. at 8.

36. See id.

37. See id at 10.

38. See Patrick J. Michaels, Global Warming: An Objective Overview, in GLOBAL WARMING AND THE KYOTO ACCORD: WHAT IS TO BE DONE? 17 (David J. Eaton ed., 2001).

39. See generally id. Michaels noted, "models cannot be proven correct, but it is very easy to prove them wrong." Id. at 19. 
might yield. ${ }^{40}$ In 2001 , the body predicted that "climate change is projected to increase threats to human health" through "reduced cold stress in temperate countries but increased heat stress, loss of life in floods and storms," changes in vectors of diseases such as malaria and dengue fever, "water-borne pathogens, water quality, air quality, and food availability and quality." 41

The body also predicted that "[s]ignificant disruptions of ecosystems from disturbances such as fire, drought, pest infestation, invasion of species, storms, and coral bleaching events are expected to increase." ${ }^{42}$ It added that "[c]limate change will exacerbate water shortages in many water-scarce areas," and that "[p]opulations that inhabit small islands and/or low-lying coastal areas are at particular risk of severe social and economic effects from sea-level rise and storm surges." 43 And while the Earth and humanity retain the capacity to adapt to some impacts of climate change, "[g]reater and more rapid climate change would pose greater challenges for adaptation and greater risks of damages than would lesser and slower changes." 44

\section{INTERNATIONAL EFFORTS TO REDUCE ATMOSPHERIC GREENHOUSE GAS LEVELS: THE ROAD TO KYOTO}

\section{A. Pre-1992 Developments leading to Collective Action}

Carbon dioxide first entered the public dialogue in the late 1970s, but the international community took few strides toward regulation for over a decade. $^{45}$ Two developments marked the international community's recognition of climate change as a viable threat. ${ }^{46}$ First, the World Meteorological Organization (WMO) and the United Nations Environment Programme (UNEP), "[r]ecognising [sic] the needs of policy-makers for

40. See generally Climate Change 2001: Synthesis Report, Intergovernmental Panel on Climate Change, at ix, available at http://www.grida.no/climate/ipcc_tar/vol4/english/index.htm (last visited Mar. 29, 2004) [hereinafter IPCC Third Report].

41. Id. at 9. The report uses "vectors of disease" to represent vehicles for disease transmission and proliferation, such as mosquitoes. See id.

42. Id. at 9,12 .

43. Id. at 12 .

44. Id. at 14 .

45. See Donald A. Brown, Climate Change, in StUMBLING Toward SuSTAINABILITY 273, 275 (John C. Dernbach ed., 2002). Brown observed that the Carter Administration was the first to recognize carbon dioxide as a potential threat to future generations but added that "global warming was not a priority of the successor Reagan Administration although international interest in climate change grew rapidly in the 1980s." Id. See also A Guide to the Climate Change Convention and its Kyoto Protocol, Climate Change Secretariat, 6 (2002), available at http://unfccc.int/resource/guideconvkp-p.pdf (last visited Mar. 29, 2004) [hereinafter Guide]. "Increasing scientific evidence of human interference with the climate system, coupled with growing public concern over global environmental issues, began to push climate change onto the political agenda in the mid-1980s." Id.

46. See Guide, supra note 45 , at 6. 
authoritative and up-to-date scientific information," established the Intergovernmental Panel on Climate Change (IPCC) in $1988 .{ }^{47}$ One year later, governments and scientists representing twenty-two countries, including Canada, France, Japan, and Italy, "called for negotiations on a global warming treaty" in recognition of "the need to reduce the threat of human-induced climate change." 48 Soon after, the IPCC issued its "First Assessment Report," which "confirm[ed] that climate change was indeed a threat and call[ed] for a global treaty to address the problem." 49

In December 1990, the UN General Assembly capped the preparations, "formally launching negotiations on a framework convention on climate change by its resolution $45 / 212$ " to be conducted by an Intergovernmental Negotiating Committee (INC). ${ }^{50}$ INC started negotiating the terms of the future treaty's framework in February 1991. ${ }^{51}$ Negotiating parties, led by the United States, immediately carved out positions on "several major contentious issues at the center of most discussions." 52 Many countries urged passage of a framework whose terms would impose far greater burdens on developed nations than those whose "governments were driven to address more urgent problems of development and basic human needs." 53

The United States, under the leadership of President George H. W. Bush, stood most firmly against pressures to establish "enforceable emission reduction targets" and urged enactment of a framework free of specific dictates. ${ }^{54}$ The United States "wanted the developing nations to accept responsibility" by industrializing in ways that would not exacerbate global warming. ${ }^{55}$ By contrast, the developing world pursued a framework that would impose greater responsibility on the industrialized world, "since the developed countries were mainly responsible for causing climate change." $\$ 6$

47. Id. See also Brown, supra note 45 , at 275 . "The specific task of the IPCC was to assess for the United Nations the scientific, technical, and socio-economic information relevant for an understanding [sic] the risk of human-induced climate change." Id.

48. Brown, supra note 45 , at 275.

49. Guide, supra note 45 , at 6 . See also Brown, supra note 45 , at 275 . The First Assessment's conclusions included the prediction that "sea-level rise and adverse effects on ecosystems ... . were likely to be caused by climate change," but conceded the "considerable scientific uncertainty about the magnitude and timing of human-induced climate change." Id.

50. Guide, supra note 45 , at 6 .

51. Id.

52. Brown, supra note 45 , at 275 . Brown explains:

Some of the most controversial issues included (1) the desirability of establishing enforceable targets and timetables to reduce GHG emissions; (2) the responsibility of developed nations to take the lead in reducing GHGs; and (3) the responsibility of developed nations to provide financial assistance to the poor nations to help them reduce GHG emissions.

Id.

53. Id. at 276.

54. Id.

55. Id.

56. Id. 


\section{B. The United Nations Framework Convention on Climate Change: Development and Entry-into-Force}

Despite standing alone on the contentious issues, the United States won the battle, successfully excluding any enforceable emission reduction targets from the draft framework. ${ }^{57}$ IPCC completed the framework on May 9, 1992, just under a month in advance of the UN Conference on Environment and Development's Earth Summit, in Rio de Janeiro, Brazil..$^{58}$ On June 4, 1992, the IPCC formally released the United Nations Framework Convention on Climate Change (Convention) to the Rio Earth Summit countries for signature. ${ }^{59}$ By the end of the Rio Earth Summit, more than 150 countries, including the United States, signed the Convention. ${ }^{60}$ The United States Senate ratified the Convention in October 1992. ${ }^{61}$ The Convention entered into force on March 21, 1994, and as of February 2003, 188 governments "(including the European Community) are now Parties to the Convention and it is approaching universal membership." 62

The Convention begins with an acknowledgment "that human activities have been substantially increasing the atmospheric concentrations of greenhouse gases, that these increases enhance the natural greenhouse effect, and that this will result on average in an additional warming of the Earth's surface and atmosphere and may adversely affect natural ecosystems and humankind." It sets as its "ultimate objective" the "stabilization of

57. Brown, supra note 45 , at 276.

58. Id. See also Guide, supra note 45 , at 6 .

59. Id. See also Convention, supra note 5.

60. Brown, supra note 45 , at 276.

61. Id.

62. Guide, supra note 45, at 6. See also United Nations Framework Convention on Climate Change, Status of Ratification (last modified on Feb. 26, 2004), available at http://unfccc.int/resource/conv/ratlist.pdf (last visited Mar. 29, 2004) [hereinafter Framework Status]. The last wave of countries ratifying the Convention occurred between 2000 and 2001 . See id. Belarus approved the Convention on May 11, 2000. See id. Angola ratified the Convention on May 17, 2000. See id. Kyrgyzstan acceded to the Convention on May 25, 2000. See id. Equatorial Guinea acceded to the Convention on August 16, 2000. See id. Bosnia and Herzegovina acceded to the Convention on September 7, 2000. See Framework Status, supra note 62. Yugoslavia ratified the Convention on March 12, 2001 (later changing its signatory name to "Serbia and Montenegro" on February 4, 2003). See id.

63. See Convention, supra note 5, at 851 . The preamble also reflects accession to the United States stances on developing-world responsibility and firm emission reduction targets. See id. It recognizes "the need for developed countries to take immediate action in a flexible manner on the basis of clear priorities ... with due consideration of their relative contributions to the enhancement of the greenhouse effect," that "all countries, especially developing countries, need access to resources required to achieve sustainable social and economic development," and that developing countries' "energy consumption will need to grow taking into account the possibilities for achieving greater energy efficiency and for controlling greenhouse gas emissions in general." Id. at 852, 853 . 
greenhouse gas concentrations in the atmosphere at a level that would prevent dangerous anthropogenic interference with the climate system." ${ }^{14}$ The Convention defines greenhouse gases as "those gaseous constituents of the atmosphere, both natural and anthropogenic, that absorb and re-emit infrared radiation." 65

Each Party signed onto a range of commitments under the Convention, according to its developmental status, socio-economic health, and ability to harness its natural resources. ${ }^{66}$ All Parties are required to "update, publish and make available" information documenting the scope of its "national inventories of anthropogenic emissions by sources and removals by sinks of all greenhouse gases not controlled by the Montreal Protocol," and undertake several other GHG management steps domestically to help reverse climate change. ${ }^{67}$ But, Parties are subject to two classes of additional commitments, depending on their level of industrial development. ${ }^{68}$ The forty-one developed country Parties fall within the Convention's "Annex I," which includes "the relatively wealthy industrialized countries" of the Western World and "countries with economies in transition" (EITs) of the former Soviet Bloc. ${ }^{69}$ The twenty-four Annex I Parties whose economies are not in transition are

64. Id. at 854. It adds that "[s]uch a level should be achieved within a time-frame sufficient to allow ecosystems to adapt naturally to climate change, to ensure that food production is not threatened and to enable economic development to proceed in a sustainable manner." Id.

65. Id. at 853. Anthropogenic gases are "human-induced," and are understood to differentiate those that occur naturally. See Beginner's Guide to the Convention, available at http://unfccc.int/resource/beginner.html (last visited Mar. 29, 2004).

66. See generally Convention, supra note 5, at 855-59.

67. Id. at 855. See also U.N. Protocol on Substances that Deplete the Ozone Layer, reproduced from text provided to International Legal Materials by the United Nations (Sept. 16, 1987), 26 I.L.M. 1541 (1987). The Montreal Protocol, opened for signature on Sept. 16, 1987, predated international consideration of the Convention and "establishe[d] specific obligations to limit and reduce use of chlorofluorocarbons and possibly other chemicals that deplete the ozone." Id.

Among the other charges, each Party must "[f]ormulate, implement, publish and regularly update" that information; promote the use of technologies "that control, reduce or prevent" GHG emissions and conservation practices; prepare for global impacts of climate change; consider socio-economic impacts of climate change; promote research into technology dedicated to sustainability; promote information exchange; and "[c]ommunicate to the Conference of the Parties information related to implementation." Convention, supra note 5, at $855-56$.

68. See generally Convention, supra note 5, at 856-89.

69. Guide, supra note 45, at 10. The Annex I parties are Australia, Austria, Belarus, Belgium, Bulgaria, Canada, Croatia, Czech Republic, Denmark, Estonia, European Community, Finland, France, Germany, Greece, Hungary, Iceland, Ireland, Italy, Japan, Latvia, Liechtenstein, Lithuania, Luxembourg, Monaco, Netherlands, New Zealand, Norway, Poland, Portugal, Romania, Russian Federation, Slovakia, Slovenia, Spain, Sweden, Switzerland, Turkey, Ukraine, United Kingdom, and United States. Id. 
also listed on the Convention's "Annex II."70 The 145 Parties not included within Annex I or II are known as "non-Annex I" Parties." The delineation of the Parties into Annex I/II and non-Annex I requires "a fundamental obligation on both industrialized and developing countries to respond to climate change," but it imposes a greater burden on industrialized Parties, who, "in order to demonstrate their leadership in addressing climate change, are subject to a specific commitment to adopt climate change policies and measures with the non-legally binding aim that they should have returned their greenhouse gas emissions to 1990 levels by the year $2000 . " 72$

The Convention also established a mechanism called the Conference of Parties (COP) to "monitor [the Convention's] implementation and continue talks on how best to tackle climate change." 73 The COP bears thirteen specific duties, including serving as a data repository for all information about climate change and the parties, recommending revisions to the Convention's structure, and all other administrative duties stemming from the Convention. ${ }^{74}$ Moreover, the Convention required the COP to hold a conference within one year of the date it entered into force and additional sessions at least once annually every year thereafter. ${ }^{75}$

\section{COP-1 and the Berlin Mandate}

As its name reflects, the Convention established a useful framework through which the international community could begin to reduce GHG and mitigate the effects of global warming. ${ }^{76}$ However, Convention Parties recognized that the Convention's "commitments would not be sufficient to

70. Id. The Annex II parties are Australia, Austria, Belgium, Canada, Denmark, European Community, Finland, France, Germany, Greece, Iceland, Ireland, Italy, Japan, Luxembourg, Netherlands, New Zealand, Norway, Portugal, Spain, Sweden, Switzerland, United Kingdom, and United States. Id.

71. Id. Among the non-Annex I Parties, some countries receive additional exemptions from the Convention due to their "particular vulnerability." Id. at 11. These Parties include those "prone to drought and desertification," whose economies "are highly dependent on income generated from fossil fuel production, processing or export." Guide, supra note 45, at 11-12.

72. Id. at 11. The delineation between Annex I and II Parties seeks to grant EITs “"a certain degree of flexibility' in implementing their commitments, on account of the economic and political upheavals recently experienced in those countries." Id. Annex II parties bear the greatest burdens, including the requirement "to provide financial resources to enable developing countries to meet their obligations ... and ... adapt to the adverse effects of climate change." Id. They must also " take all practicable steps' to promote the development and transfer of environmentally-friendly technologies to both EITs and developing countries." Id.

73. Id. at 6. The Convention defines "climate change" as "a change of climate which is attributed directly or indirectly to human activity that alters the composition of the global atmosphere and which is in addition to natural climate variability observed over comparable time periods." Convention, supra note 5 , at 853 .

74. Convention, supra note 5 , at 860,861 .

75. Id. at 862 .

76. See generally id. 
seriously tackle climate change."77 As a result, the Parties sought to empower the COP to augment the original document with mechanisms that would more effectively reduce greenhouse gas volumes. ${ }^{78}$ The Parties marked this recognition at the first COP session (COP-1), which opened in Berlin, in March $1995 .{ }^{79}$ The session's tone was colored by the recent publication of IPCC's Second Assessment Report, which announced that "not only was human-induced climate change a real issue with likely adverse impacts to human health and the environment . . . but that it was possible to observe actual effects of human activities on climate that could be distinguished from natural climate variability." ${ }^{\text {"I }}$ In view of the new scientific conclusions, the collected Parties of COP-1 called for a more comprehensive set of commitments. ${ }^{81}$

The pronouncement, known as the Berlin Mandate, "launched a new round of talks to decide on stronger and more detailed commitments for industrialized countries." 82 The Mandate called for "a process to . . . strength[en] the commitments of the [Annex I] Parties . . . in Article 4, paragraph 2(a) and (b), through the adoption of a protocol or another legal instrument." ${ }^{83}$ It stipulated that the process needed to "elaborate policies and measures" and include "quantified [emissions] limitation and reduction

77. Guide, supra note 45, at 6. See also Brown, supra note 45, at 288 . "By 1995 , it was becoming quite clear that the weak nonbinding approaches to global warming contained in the UNFCCC were failing to make much progress on the growing global warming problem." Id.

78. Guide, supra note 45 , at 6 .

79. Id.

80. Brown, supra note 45, at 289. The IPCC's Second Assessment Report also highlighted "likely global warming impacts to human health and the environment. These included rising temperatures and oceans, adverse impacts to ecosystems, biodiversity, forests, water supplies, and human health, increased droughts, floods, and tropical storms for parts of the worlds, and negative impacts on farming for some parts of the world." Id.

81. Guide, supra note 45, at 6. See also, Clare Breidenich, Daniel Magraw, Anne Rowley \& James W. Rubin, The Kyoto Protocol to the United Nations Framework Convention on Climate Change, 92 AM. J. INT'L L. 315,318 (1998). The Parties decided the Convention was inadequate for three reasons:

First, national projections of GHG emissions indicated that most Annex I countries were not on track to meet the Convention's emissions aim for the year 2000. Second, the Convention contained no provision related to GHG emissions for the period after 2000 . Finally, parties recognized that stabilization of GHG emissions at 1990 levels would not be sufficient to stabilize atmospheric GHG concentrations.

Id.

82. Guide, supra note 45 , at 6 .

83. UNFCCC Conference of Parties: Decisions Adopted by the First Session (Berlin), reproduced from UN Doc. FCCC/CP/1995/7/Add.1 (June 6, 1995), 34 I.L.M. 1671, 1676 (1995) [hereinafter Berlin Mandate]. Article 4.2(a) and (b) of the Convention called for "the return by the end of the present decade to earlier levels of anthropogenic emissions of carbon dioxide and other greenhouse gases not controlled by the Montreal Protocol" and reporting of each Party's progress toward this end, but called for no commitments after 2000 . Convention, supra note 5 , at 856 . 
objectives [QELROs] within specified time-frames ... for their anthropogenic emissions by sources and removals by sinks of greenhouse gases not controlled by the Montreal Protocol." 84 Moreover, the Mandate declared that any protocol adopted should not demand new commitments from non-Annex I Parties, "in order [for those Parties] to achieve sustainable development." Finally, COP-1 created a new "ad hoc group of parties" to negotiate a protocol reflecting these goals in advance of COP-3, set to take place in Kyoto, Japan, in $1997 .{ }^{86}$

\section{The Kyoto Protocol: The Addition of Enforceable Emissions Targets to the Framework Convention}

The United States changed its tack in 1996, when President Bill Clinton announced his willingness to negotiate binding GHG emissions limitations. ${ }^{87}$ Nevertheless, "[m]any nations vehemently opposed the U.S. position on the basis that more stringent cuts in emissions were necessary to prevent global warming from getting out of hand." ${ }^{88}$ While the United States urged extension

84. Berlin Mandate, supra note 83 , at 1677 . One set of commentators notes that "QERCOs are essentially targets for emissions reductions. Policies and measures are essentially items that parties adopt and act upon to attain their QELROs.” Breidenich, Magraw, Rowley \& Rubin, supra note 81, at 331.

85. Berlin Mandate, supra note 83, at 1677 . The Berlin Mandate's emphasis on industrialized Parties' commitments reflected "the view of many of the developing countries . . that it is the responsibility of the industrialized countries to adopt significant measures to reduce their GHG emissions before the developing countries might place their economic development at risk by adopting any similar measures." Breidenich, Magraw, Rowley \& Rubin, supra note 81 , at 319.

86. See Berlin Mandate, supra note 83 , at 1678.

87. See Brown, supra note 45 , at 289. While President Clinton expressed a willingness to negotiate workable emission limitations under the Convention, the U.S. Senate was open in its opposition to binding supernational emissions targets. See generally Byrd-Hagel Resolution, S. Res. 98, 105th Cong., 143 ConG REC S8113-05 (1997) (enacted). Nevertheless, Clinton announced on Oct. 22, 1997, that the United States would "agree to stabilize GHG emissions at 1990 levels by 2012," extending its pledge under the Convention another twelve years. Brown, supra note 45, at 289.

88. Brown, supra note 45 , at 289 . Under Clinton's offered concessions, reducing U.S. emissions to 1990 levels by 2012 "would be a reduction of 23 to $30 \%$ below what emissions would otherwise be," without negotiating the additional cuts called for by other Parties. Id. at 290. One commentator notes

this was so because the United States had done little after Rio to prevent emissions from spiraling upward. Five years after signing the UNFCCC, the United States had further to go than many other nations to reduce emissions to 1990 levels, in part because it only had adopted mild voluntary programs and Congress was not interested in doing much more. Much of the world was not sympathetic with the predicament the United States had created by its own inaction.

Id. 
of the 1990 targets, other Parties pushed for more stringent, specific targets. ${ }^{89}$ Despite the passage of time, the approach of COP-3 revealed that the division of opinions over shared responsibilities between the developed and developing worlds had not dissipated. ${ }^{90}$

On December 1, 1997, more than 160 Convention Parties collected in Kyoto, Japan, for the COP-3 session. ${ }^{91}$ The session opened more than five years after the unveiling of the Convention at the Rio Earth Summit. ${ }^{92}$ As days passed at the session, many feared that an impasse between the United States and the rest of the Parties would destroy the possibility of a protocol in line with the Berlin Mandate. ${ }^{93}$ However, the Parties connected on terms on December 11, 1997, when the United States agreed to commit to a seven percent reduction below 1990 levels in exchange for a range of concessions that shaped what came to be the Kyoto Protocol. ${ }^{94}$

The Protocol "supplements and strengthens the Convention" and shares its "ultimate objective and principles, as well as its grouping of countries into Annex I, Annex II . . . and non-Annex I Parties." strengthening rests in its binding emissions targets and timetables, which, "when taken together, should lead by 2012 to an overall reduction of emissions levels to [five] percent below 1990 levels." 96 The Protocol consists of five main elements: (1) Commitments, (2) Implementation, (3) Minimizing impacts on developing countries, (4) Accounting, reporting and review, and (5) Compliance. ${ }^{97}$

The Protocol binds Annex I Parties to "substantive commitments," including specific emission targets (QELROs), ${ }^{98}$ and it "further elaborates FCCC commitments for all Parties." "99 The targets are set "against base year

89. Id. In the summer of 1997, the European Union proposed that "developed countries commit to reduce emissions for three GHGs by $15 \%$ below 1990 levels by the year 2010 , with an interim target of $7.5 \%$ by the year 2005 ," whereas a group of seventy-seven developing countries, joined with China, pushed for similar reductions, plus emission targets $35 \%$ below 1990 levels by 2020 . Id.

90. Id. at 289.

91. See Breidenich, Magraw, Rowley \& Rubin, supra note 81, at 315 .

92. See generally id.

93. See Brown, supra note 45 , at 290.

94. See id. at 291. See also Protocol, supra note 5.

95. Guide, supra note 45, at 21. The Protocol also adopted the Convention's Conference of Parties as its "meeting of the Parties," and changed the body's name to COP/MOP. Id.

96. Sean D. Murphy ed., Kyoto Protocol to Climate Change Convention, 93 AM. J. INT'L L. 491, 491-92 (1999).

97. Guide, supra note 45 , at 21-22.

98. QELRO stands for quantified emissions limitation and reduction objectives. See Breidenich, Magraw, Rowley \& Rubin, supra note 81, at 319.

99. Id. at 319. The authors note

The Kyoto Protocol thus contains substantive commitments in all three areas specified by the Berlin Mandate: binding emission reduction targets (i.e., QELROs) for industrialized countries, a requirement for industrialized countries to implement or further elaborate appropriate policies and measures to meet their 
emission levels." 100 The actual percentages are listed in Annex B of the Protocol. $^{101}$ Each Annex I Party's reduction commitment for the 2008-12 period is equal to an assigned percentage of its "aggregate anthropogenic carbon dioxide equivalent emissions" in 1990 or other relevant base year, multiplied by five. ${ }^{102}$ The ninety-three percent commitment assigned to the United States, for instance, required it to reduce by seven percent its total 1990 GHG emissions amount by 2008-12. ${ }^{103}$ Once other requirements of the Protocol are factored, all Parties' commitments taken together represent a 5.2 percent reduction in global emissions. ${ }^{104}$

One commentator noted, "The determination of reduction commitments for the Annex I Parties was one of the most contentious issues in the negotiations (because they contemplated and resulted in) ... differentiated targets for individual Parties." 105 European and United States detractors chided the negotiations for imposing no commitments on developing countries and placing the burdens on industrialized ones. ${ }^{106}$ Nonetheless, the United States signed the Protocol in the conference's waning moments, largely due to the inclusion of a series of "flexibility mechanisms" allowing innovative ways for Parties to comply with their commitments. ${ }^{107}$

QERLOs as established by Article 3 of the Protocol, and provisions that reaffirm and seek to advance the implementation of certain commitments that pertain to all FCCC parties.

Id. at 319-20.

100. Id. The base year is 1990 for most parties. See id. Turkey is the sole Annex I party, for which the Protocol assigns no QELROs. See id. Countries with "economies in transition"--largely, former Soviet Bloc members-are either authorized to use a different base year or apply to do so. Id. At COP-8, held in New Delhi, India, in 2002, the Parties agreed to allow Bulgaria and Poland to use 1988 as their base years, Romania to use 1989, Slovenia to use 1986, and Hungary to use the average of the years between 1985 and 1987. See Review of the Implementation of Commitments and of Other Provisions of the Convention, Conference of the Parties, Eighth Session, New Delhi, FCCC/CP/2002/8, at 5, available at http://unfccc.int/resource/docs/cop8/08.pdf (last visited Mar. 29, 2004).

101. See Protocol, supra note 5, at 42.

102. Id. at 34. The United States emission reduction commitment (QELRO) is ninety-three percent. Id. at 42 . All members of the European Community are committed to ninety-two percent each. Id. Iceland and Australia's commitments are among the highest, at 110 percent and 108 percent each. Id. With values greater than 100 percent, Iceland and Australia are each permitted net percentage increases over their base year emissions amounts. Id.

103. See Guide, supra note 45, at 22.

104. Breidenich, Magraw, Rowley \& Rubin, supra note 81, at 320.

105. Brendan P. McGivern, Introductory Note: Conference of the Parties to the Framework Convention on Climate Change: Kyoto Protocol, 37 I.L.M. 22, 24 (1997).

106. See Brown, supra note 45 , at 291. Supporters of differentiated targets, including Australia, Japan, Norway, and Iceland, argued that uniform targets were inappropriate "owing to the vast differences in countries' national circumstances, particularly natural resources and energy production and consumption profiles." Breidenich, Magraw, Rowley \& Rubin, supra note 81 , at 320 .

107. Breidenich, Magraw, Rowley \& Rubin, supra note 81, at 320. 
Those mechanisms include (1) emissions banking, (2) joint implementation, (3) clean development, and (4) international emissions trading. ${ }^{108}$ Emissions banking is authorized by Article 3.13, and provides Parties that do not exceed their assigned amounts an opportunity to allocate their unused allotments for use in "subsequent commitment periods." 109 Joint implementation, authorized by Article 6,110 "allows developed nations with emissions targets to obtain credit toward the target by doing emission reduction projects in other nations that have targets." 111 Parties using the joint implementation mechanism "may transfer to, or acquire from, any other ... [Annex I] Party emission reduction units resulting from projects aimed at reducing anthropogenic emissions by sources or enhancing anthropogenic removals by sinks of greenhouse gases in any sector of the economy."112

Clean development, authorized by Article $12,{ }^{113}$ seeks to accomplish the concurrent goals of helping developing countries "achiev[e] sustainable development and in contributing to the ultimate objective of the Convention," and helping industrialized countries "achiev[e] compliance with their [QELROs]." 114 For example, an Annex I party that helps a non-Annex I party industrialize its economy through clean technologies "may use the certified emission reductions accruing from such project activities to contribute to compliance" with their own QELROs. ${ }^{115}$

Among the mechanisms, emissions trading received most of the attention at Kyoto and it has continued to do so since. ${ }^{116}$ Emissions trading is authorized by Article 17, and though the Parties did not agree in Kyoto to "much detail on the type of system," the Protocol provided a framework upon which the COP could build. ${ }^{117}$ Under this mechanism, "[a] party with an emission reduction commitment (i.e. a Party in Annex B) could 'buy' part of the emissions budget of another Annex B Party where it would be more cost effective for it to do so than to undertake the reduction domestically."118

108. See McGivern, supra note 105, at 26-27.

109. Protocol, supra note 5, at 34.

110. See id at 35.

111. Brown, supra note 45, at 291.

112. Protocol, supra note 5, at 35 . Joint implementation is also known as project-based credit transfer. See Breidenich, Magraw, Rowley \& Rubin, supra note 81, at 324.

113. See id at 38.

114. Id.

115. Id. The emissions resulting from this mechanism "shall be certified by operational entities to be designated by [the COP]." Id.

116. See McGivern, supra note 105, at 26.

117. Breidenich, Magraw, Rowley \& Rubin, supra note 81 , at 324.

118. McGivern, supra note 105 , at 26 . The ability stems from Article 4.2 of the Convention, which states that "[p]arties may implement such policies and measures jointly with other Parties and may assist other Parties in contributing to the achievement of the objective of the Convention." Convention, supra note 26, at 856 . At its introduction, the Protocol included no specific language dictating the operation of the emissions trading system, but Article 3 "simply authorize[d] Annex B countries to participate in emissions trading with each other and 
Article 16bis provides that the COP would define all terms of emission trading, that Parties "may participate in emissions trading for the purposes of fulfilling their commitments under Article 3," and that "[a]ny such trading shall be supplemental to domestic actions for the purpose of meeting [QELROs]."119

The Clinton Administration was largely responsible for the inclusion of flexibility mechanisms in the Kyoto Protocol, convincing the COP that market-based solutions would help countries achieve meaningful emissions reductions while avoiding the economic consequences feared by many critics in the developed world. ${ }^{120}$ John D. Gibson, a former Senior Counsel to the White House Task Force on Global Climate Change under President Clinton, called Kyoto "a good deal for the earth, and ... an even better deal for the United States," due to the flexible means through which Parties can meet their targets. ${ }^{121}$ The Protocol, Gibson noted, "gives nations flexibility about how to meet their targets," about "when they achieve their reductions," and enables Parties to "[d]o wherever is the cheapest first."122 For example, the United States, Thailand, and the global community benefit through use of joint implementation, where "an American company, for instance, could get emissions reduction credits by investing in a solar energy project in Thailand. We get the emission credits; Thailand gets cleaner air, and the transfer of environmentally friendly technologies." 123

As of February 2004, the Protocol had not entered into force. ${ }^{124}$ Article 24 of the treaty requires that "not less than [fifty-five] Parties to the Convention" must ratify, accept, approve, or accede to the Protocol before it enters into force. ${ }^{125}$ Moreover, the aggregate emissions of the ratifying Parties must account for "at least [fifty-five] per cent of the total carbon dioxide

to use such trading to meet emission target commitments ...." Breidenich, Magraw, Rowley \& Rubin, supra note 81, at 324.

119. Protocol, supra note 5, at 40.

120. See Brown, supra note 45, at 291.

121. John D. Gibson, Why the Kyoto Protocol Makes Sense for the United States, in Global WARMING AND THE KYOTO ACCORD: What IS TO BE DONE? 57, 58 (David J. Eaton ed., 2001).

122. Id. at 58, 59. The Protocol allows flexibility in how Parties meet their targets through several means, but notably through the use of "sinks activities," or "[a]ctivities that absorb carbon, such as planting trees, [which] can offset emissions . . . [and] has the potential to cut the cost of [United States'] compliance very dramatically." Id. at 58. It provides flexibility with when Parties can meet their targets by "stat[ing] targets in terms of average emissions over five years, 2008 to 2012, to smooth out short-term fluctuations due to economic performance or weather." Id. And, it provides flexibility with where Parties can meet their targets through cooperation between Parties and by solving the easiest emissions challenges first. Id. at 59 .

123. Id. Gibson adds, "The earth's atmosphere doesn't care whether a ton of $\mathrm{CO}_{2}$ reductions occur in the United States, Ukraine, or China. The earth's atmosphere doesn't care whether we reduce carbon emissions by a ton or sequester a ton of carbon by planting trees." Gibson, supra note 121 , at 60.

124. See generally Protocol Status, supra note 8.

125. Protocol, supra note 5, at 41. 
emissions for 1990 of the Parties included in Annex I" before the Protocol enters into force. ${ }^{126}$ Through the end of September 2003, 119 Parties ratified, accepted, approved, or acceded to the Protocol. ${ }^{127}$ But, because the combined emissions of those Parties accounts for only 44.2 percent of the 1990 global total, the Protocol has not reached its triggering goal. ${ }^{128}$ Protocol backers expect Russia to ratify the treaty, and that the industrial giant's contribution to the 1990 emission total (seventeen percent) will push the treaty into force. ${ }^{129}$ However, the certainty of Russia's ratification started to fade in September 2003, when President Vladimir Putin backed away from his earlier open support of the Protocol. ${ }^{130}$ As one commentator recognized in October 2003, if the United States does not ratify the Protocol, "every other major industrial country on the planet had to ratify it before it could come into effect. ... If Russia pulls out, the treaty dies." 131

\section{E. Developments after Kyoto: The United States' initial reluctance to ratify the Protocol and to institute domestic GHG reductions}

The United States bears a thirty-six percent share of the 1990 global total of carbon dioxide emissions, but as arguably the most important country on the planet, its absence from the Protocol casts a shadow over the treaty's future regardless of percentages. ${ }^{132}$ President George W. Bush has unequivocally opposed the Protocol since taking office, but American opposition to its tenets predates his inauguration. ${ }^{133}$ As discussed, President Clinton's representatives negotiated Kyoto's terms, but the administration's support of binding, international emissions limitations clashed with the

126. Id.

127. See generally Protocol Status, supra note 8.

128. Id. Ratifying Parties with significant global emissions percentages include Japan ( 8.5 percent), Germany (7.4 percent), United Kingdom (4.3 percent), Canada ( 3.3 percent), Italy (3.1 percent), Poland ( 3.0 percent), and France ( 2.7 percent). $I d$.

129. See Glasser, supra note 8.

130. Id. In 1997, Putin said of the treaty, "Russia actively stands for the quickest possible ratification of the Kyoto Protocol.” Id. However, Putin spoke hesitantly about Russia's intentions before a global environmental conference held in Moscow in September 2003. Id. One month later, Putin injected additional uncertainty about his country's position, announcing that unlike "the USA, [which] withdrew from the Kyoto protocol . . . we didn't." Putin Says Russia Must Not Become Kyoto Protocol's "Milch Cow", BBC MONITORING INT'L REP., Oct. 19, 2003. The Russian President added that "it will not be easy to talk the Russian State Duma into" ratification of the existing Protocol language, that the commitments of all Parties "must be fair," and that he did "not want Russia to become a milch (sic) cow at the expense of which environmental problems are tackled." Id.

131. Gwynne Dyer, Putin Softens Kyoto Stance, GuElPH MerCURY, Oct. 2, 2003, at A11.

132. See generally Glasser, supra note 8.

133. See generally Greg Kahn, Between Empire and Community: The United States and Multilateralism 2001-2003: A Mid-Term Assessment: ENVIRONMENT: The Fate of the Kyoto Protocol Under the Bush Administration, 21 BERKELEY J. INT'L L. 548 (2003). 
prevailing political sentiment in Washington at the time. ${ }^{134}$ Even while American negotiators cheered the inclusion of flexibility mechanisms into the final treaty, Congress took steps that mooted the work of the President's team. ${ }^{135}$

First, the U.S. Senate unanimously passed the Byrd-Hagel Resolution ${ }^{136}$ in 1997, which served notice to President Clinton that any effort to submit the Protocol for ratification as written would result in political defeat. ${ }^{137}$ As it bears the sole power to ratify treaties under the Constitution, the Senate preempted the President's course of action on the Protocol. ${ }^{138}$ The bipartisan measure stated:

the United States should not be a signatory to any protocol to, or other agreement regarding [UNFCCC] . . . at negotiations in Kyoto in December 1997, or thereafter which would . . . mandate new commitments to limit or reduce greenhouse gas emissions for the Annex I Parties, unless the protocol or other agreement also mandates new specific scheduled commitments to limit or reduce greenhouse gas emissions for Developing Country Parties within the same compliance period, or ... would result in serious harm to the economy of the United States. ${ }^{139}$

In addition to the Byrd-Hagel Resolution's stern warning, Congress undertook a systematic blockade of any Clinton Administration funding requests for programs associated with GHG reduction or climate change research. ${ }^{140}$ One commentator noted that Congress effectively prohibited all

134. See Brown, supra note 45 , at 291.

135. Id.

136. See Byrd-Hagel Resolution, S. Res. 98, 105th Cong., 143 Cong REC S81 13-05 (1997) (enacted).

137. See id.

138. See U.S. ConST. art. II, $\& 2$. The section provides that the President "shall have Power, by and with the Advice and Consent of the Senate, to make Treaties, provided two-thirds of the Senators present concur." Id.

139. Byrd-Hagel Resolution, S. Res. 98, 105th Cong., 143 ConG REC S8113-05 (1997) (enacted). The resolution also called for "an analysis of the detailed financial costs and other impacts on the economy of the United States which would by incurred by the implementation of the protocol" to accompany any treaty such as Kyoto in an effort to seek ratification. Id.

140. See, e.g., H.R. CONF. REP. No. 106-914, P.L. 106-914 (2000). Section 329 of this act, a 2000-01 spending measure for the Department of the Interior and other agencies, reads:

None of the funds appropriated by this Act shall be used to propose or issue rules, regulations, decrees, or orders for the purpose of implementation, or in preparation for implementation, of the Kyoto Protocol ... which has not been submitted to the Senate for advice and consent to ratification pursuant to article II, section 2, clause 2, of the United States Constitution, and which has not entered into force pursuant to article 25 of the Protocol. Id. at 76. 
work "on climate issues that could be construed as 'back door' ratification of the Kyoto Protocol," and that "[t]his would prove to greatly hinder EPA from working with states and local governments who desired to take voluntary steps to reduce GHG emissions." ${ }^{141}$ President Clinton continued to spar with Congress on all fronts of the global climate debate through the end of his term in 2000. ${ }^{142}$ As a result, "not much was done during the Clinton Administration to reduce U.S. emissions of GHG other than some efficiency improvements encouraged by voluntary programs." 143 Because the United States implemented no carbon dioxide emissions reduction measures, even as required by its ratification of the Convention, "U.S. greenhouse emissions continued to soar" during this period. ${ }^{144}$

However, the EPA under President Clinton did not cave to Congress' efforts to bar domestic consideration of carbon dioxide regulation. ${ }^{145}$ During 1998 hearings before the House Appropriations Committee, Rep. Thomas DeLay (R-Tex.) asked EPA Administrator Carol M. Browner to issue a formal opinion regarding the agency's authority to regulate carbon dioxide under the Clean Air Act. ${ }^{146}$ In response to that request, the EPA's Office of General Counsel issued a legal memorandum, providing that the agency could regulate carbon dioxide within the existing framework of the Clean Air Act. ${ }^{147}$ EPA

See also, H.R. REP. No. 107-116 (2001). This spending bill, for the Department of Agriculture, rural development programs, the Food and Drug Administration, and other related agencies, featured nearly identical language, despite coming one year later and in a different department. See id. at 118.

141. Brown, supra note 45, at 291.

142. See 143 CONG. REC. S11007-01 (1997). President Clinton wanted to pursue other climate change legislation in advance of Protocol ratification, announcing on October 22, 2003, "I want to emphasize that we cannot wait until the treaty is negotiated and ratified to act." Id. In response, Byrd-Hagel co-author Senator Chuck Hagel, R-NE, addressed the Senate, stating

What President Clinton proposed yesterday is for the American people to bear the cost and suffer the pain of a treaty that will not work. That is the legacy, or more appropriately the lunacy he would leave to the children of America. ... We can do better. We must do better. Our future generations are counting on us to do better.

Id. at $\mathrm{S} 11008-01$.

143. Brown, supra note 45, at 291. Brown noted that Congress was "not only hostile to the Kyoto Protocol," but also against "taking any serious steps to reduce U.S. emissions." Id.

144. Id.

145. See generally Memorandum from Jonathan Z. Cannon, General Counsel, to Carol M. Browner, Environmental Protection Agency Administrator (Apr. 10, 1998) (on file with author) [hereinafter Cannon Memorandum].

146. See id. Senator DeLay referred to an EPA document entitled, "Electricity Restructuring and the Environment: What Authority Does EPA Have and What Does it Need," which stated that EPA already had authority under the Act to "establish pollution control requirements for four pollutants of concern from electric power generation: nitrogen oxides (NOx), sulfur dioxide $\left(\mathrm{SO}_{2}\right)$, carbon dioxide $\left(\mathrm{CO}_{2}\right)$, and mercury." Id. EPA Administrator Browner announced that the Clean Air Act provided such authority and promised to produce a legal opinion on behalf of her agency. See id.

147. See id. 
General Counsel Jonathan Z. Cannon wrote that "the Clean Air Act provides EPA authority to address air pollution, and a number of specific provisions of the Act are potentially applicable to control these pollutants from electric power generation." 148 More importantly, Mr. Cannon recognized that "air pollutant[] ... [is] broadly defined under the Act and include[s] $\ldots \mathrm{CO}_{2} \ldots$ emitted into the ambient air." ${ }^{49} \mathrm{He}$ added "[w]hile $\mathrm{CO}_{2}$, as an air pollutant, is within EPA's scope of authority to regulate, the Administrator has not yet determined that $\mathrm{CO}_{2}$ meets the criteria for regulation under one or more provisions of the Act." 150 However, Cannon recognized that "[s]pecific regulatory criteria under various provisions of the Act could be met if the Administrator determined under one or more of those provisions that $\mathrm{CO}_{2}$ emissions are reasonably anticipated to cause or contribute to adverse effects on public health, welfare, or the environment."

Later in 1999, Cannon's successor Gary S. Guzy testified before a House subcommittee and affirmed his predecessor's opinions about the EPA's authority to regulate carbon dioxide. ${ }^{152}$ Guzy announced that the EPA "ha[d] no intention of implementing the Kyoto Protocol ... prior to its ratification," and that "there is a clear difference between actions that carry out authority under the Clean Air Act or other domestic law, and actions that would implement the Protocol."153 However, Guzy went on to clarify that although "EPA has not made any of the Act's threshold findings that would lead to regulation of $\mathrm{CO}_{2}$ emissions from electric utilities or, indeed, from any source $\ldots \mathrm{CO}_{2}$ is in the class of compounds that could be [regulated]."154

\section{F. The 21st Century: IPCC's Third Assessment Report and the United States' continuing reluctance to regulate GHGs}

The EPA's policy floating elevated the debate during the close of the Clinton Administration, but the fact remained that the United States had

148. Id. at 2.

149. Cannon Memorandum, supra note 145, at 3. Mr. Cannon recognized that the Act requires EPA to regulate "each air pollutant that causes or contributes to air pollution that may reasonably be anticipated to endanger public health or welfare and that is present in the ambient air due to emissions from numerous or diverse mobile or stationary sources." Id. .

150. Id. at 4.

151. Id. at 4-5.

152. See generally Is $\mathrm{CO}_{2}$ a Pollutant and Does EPA Have the Power to Regulate It?: Joint Hearing of the Subcomm. on Nat'l Econ. Growth, Natural Res. and Regulatory Affairs of the Comm. on Gov't Reform and the Subcomm. on Energy and Env't of the Comm. on Science, U.S House of Representatives, 106th Congress (1999) (Testimony of Gary S. Guzy, General Counsel, U.S. EPA), available at http://www.house.gov/science/guzy_100699.htm (last visited Mar. 15, 2004) [hereinafter Guzy Testimony].

153. Id. Guzy added, "there is nothing inconsistent in assessing the extent of current authority under the Clean Air Act and maintaining our commitment not to implement the Protocol without ratification." Id.

154. Id. 
enacted no meaningful GHG emissions reductions or climate change legislation through $2000 .{ }^{155}$ However, the transition of the presidency to George W. Bush likewise manifested a transition from executive branch support for the Kyoto process to outright hostility toward it. ${ }^{156}$ The source of disconnect between the Bush and Clinton Administrations, other than partisan posturing, laid in the difference between the two camps' economic cost estimates of compliance with the emissions reductions limitations. ${ }^{157}$ Clinton Administration studies forecast that Kyoto compliance, including the use of international emissions trading, would "cost the average American family about $\$ 70$ to $\$ 110$ a year." 158 While Bush Administration officials have not settled on one figure, the Administration has pronounced that compliance with the Protocol would be "potentially prohibitive," that "drastic cuts in emissions will have serious repercussions on the U.S. economy," and that "the economic sacrifices made by the United States would be greater than that of any other country." 159

In addition to public statements made by several of his top advisors early in his term, President Bush wasted little time letting the Senate know that he shared its opposition to the Protocol and would not submit the treaty for ratification. ${ }^{160}$ In a formal letter to members of the Senate, President Bush stated:

As you know, I oppose the Kyoto Protocol because it exempts 80 percent of the world, including major population centers such a China and India, from compliance, and would cause serious harm to the U.S. economy. The Senate's vote, 95-0, shows that there is a clear consensus that the Kyoto Protocol is an unfair and ineffective means of addressing global climate change concerns. ${ }^{161}$

155. See Brown, supra note 45, at 291.

156. See Kahn, supra note 133 , at 551.

157. Id. at 557.

158. Gibson, supra note 121 , at 61 . The former senior counsel to President Clinton added that this cost estimate also required "other common-sense measures like restructuring our electricity," and does not account for the "very large benefits that would come . . from not having to build sea walls around Miami, Manhattan, or Corpus Christi; not having the corn or citrus belts shift a couple of hundred miles north; or not having to fight dengue fever outbreaks in Kansas City." Id.

159. Kahn, supra note 133, at 557.

160. Id. at 551. See also, Letter to Members of the Senate on the Kyoto Protocol on Climate Change, 37 WEEKLY COMP. PRES. DOC. 444445 (Mar. 19, 2001).

161. Id. The President added, "I do not believe, however, that the government should impose on power plants mandatory emissions reductions for carbon dioxide, which is not a 'pollutant' under the Clean Air Act." Id. This statement represented a reversal for President Bush on a campaign promise to pursue emissions control limits, and undercut his new EPA Administrator Christine Todd Whitman, who had stated days earlier that the administration was pursuing mandatory power plant emissions limits. See Kahn, supra note 133, at 551. 
To affirm his stance, President Bush enlisted the National Academy of Sciences to study GHG and climate change and produce a report that would "identif[y] the areas in the science of climate change where there are the greatest certainties and uncertainties." ${ }^{162}$ The twelve-person Committee on the Science of Climate Change of the National Academy of Science's National Research Council issued its report on June 7, 2001, announcing that "[g]reenhouse gases are accumulating in Earth's atmosphere as a result of human activities, causing surface air temperatures and subsurface ocean temperatures to rise." 163 The Council noted that it "generally agree[d] with the assessment of human-caused climate change presented in the IPCC Working Group I (WGI) scientific report," undercutting the Bush Administration's claims that IPCC slanted its scientific findings when it published its "Summary for Policymakers."164 Moreover, the scientific panel announced that

An effective strategy for advancing the understanding of climate change also will require (1) a global observing system in support of long-term climate monitoring and prediction, (2) concentration on large-scale modeling through increased, dedicated supercomputing and human resources, and (3) efforts to ensure that climate research is supported and managed to ensure innovation, effectiveness, and efficiency. ${ }^{165}$

Meanwhile, the IPCC adopted the final part of its Third Assessment Report at its September 2001 session in Wembley, England. ${ }^{166}$ The panel shaped its 2001 report to answer the COP's specific concerns about "issues such as the extent to which human activities have influenced and will in the future influence the global climate, the impacts of a changed climate on ecological and socio-economic systems, and existing and projected technical and policy capacity to address anthropogenic climate change." 167 The report included the most unequivocal language about human influence on climate

162. NRC Report, supra note 28, at App. A.

163. Id. at 1. NRC also announced that atmospheric carbon dioxide concentrations were rapidly increasing, and that "[h]uman activities are responsible for the increase." Id. at 2.

164. Id. at 1, 4. NRC recognized that IPCC's scientific reports were "an admirable summary of research science," and that the Summary for Policymakers "reflect[ed] less emphasis on communicating the basis for uncertainty and a stronger emphasis on areas of major concern associated with human-induced climate change." Id. at 4. It added, however, that the scientists worked with the policymakers to produce the summary, and that "no changes were made without the consent of the convening lead authors." Id.

165. NRC Report, supra note 28 , at 5.

166. See generally IPCC Third Report, supra note 40.

167. Id. at vii. 
change in the history of the Convention and IPCC's charter. ${ }^{168}$ For the first time, the UN's scientists announced, "Human activities have increased the atmospheric concentrations of greenhouse gases and aerosols since the preindustrial era," and that "atmospheric concentrations of key anthropogenic gases ... reached their highest recorded levels in the 1990s, primarily due to the combustion of fossil fuels, agriculture, and land-use changes."169 They recognized, at a ninety to ninety-nine percent chance of likelihood, that "the 1990 s was the warmest decade, and 1998 the warmest year" between 1861 and $2000 .{ }^{170}$

While IPCC yielded that the projected climate change would provide some benefits to global environmental and socio-economic systems, it concluded that the benefits would "diminish as the magnitude of climate change increases." ${ }^{171}$ In contrast, IPCC projected that adverse environmental and socio-economic effects will likely increase as the magnitude of climate change and GHG emissions increase. ${ }^{172}$ The report projected these adverse developments under scenarios where global carbon dioxide emission levels increased or stabilized. ${ }^{173}$ However, it recognized that the "projected rate and magnitude of warming and sea-level rise can be lessened by reducing greenhouse gas emissions." ${ }^{174}$ It added, "[r]educing emissions of greenhouse gases to stabilize their atmospheric concentrations would delay and reduce damages caused by climate change." ${ }^{175}$ IPCC yielded that its studies had not revealed "[c]omprehensive, quantitative estimates of the benefits of

168. See id. at 4.

169. Id.

170. Id. Using a range of climate models, IPCC projected that global average surface temperatures will continue to increase 1.4 to 5.8 degrees centigrade between 1990 and 2100 if the global community institutes no climate policy intervention. Id. at 8 . This increase will result from projected carbon dioxide atmospheric concentration increases to between 540 and 970 parts per million ( $\mathrm{ppm}$ ), "compared to about $280 \mathrm{ppm}$ in the pre-industrial era and about $368 \mathrm{ppm}$ in the year 2000." IPCC Third Report, supra note 40, at 8.

171. Id. at 9.

172. Id. The report noted, "[c]limate change can affect human health directly (e.g. reduced cold stress in temperate countries but increased heat stress, loss of life in floods and storms) and indirectly through changes in the ranges of disease vectors (e.g., mosquitos), water-borne pathogens, water quality, air quality, and food availability and quality." Id. It also projects increases in pest infestations, exacerbated water shortages, degraded freshwater quality, increased coastal floods and erosion, coral bleaching, melting of polar ice sheets, and a rise in sea level. Id. at $9,12,21$.

173. See id. at 14, 16. IPCC noted, "Stabilization of $\mathrm{CO}_{2}$ concentrations at any level requires eventual reduction of global $\mathrm{CO}_{2}$ net emissions to a small fraction of the current emission level. The lower the chosen level for stabilization, the sooner the decline in global net $\mathrm{CO}_{2}$ emissions needs to begin." IPCC Third Report, supra note 40, at 16.

174. Id. at 19. To stabilize "atmospheric $\mathrm{CO}_{2}$ concentrations at 450,600 , or $1,000 \mathrm{ppm}$ ... global anthropogenic $\mathrm{CO}_{2}$ emissions ... [must] drop below the year 1990 levels, within a few decades, about a century, or about 2 centuries, respectively, and continue to decrease steadily thereafter." Id. "Eventually $\mathrm{CO}_{2}$ emissions would need to decline to a very small fraction of current emissions." Id.

175. Id. at 21 . 
stabilization at various levels of atmospheric concentrations of greenhouse gases." 176 As a result, the body stopped short of publishing statistics with which policy makers could compare costs of mitigation efforts against the long-term costs of inaction. ${ }^{177}$

In spite of the emergence of the new data in IPCC's Second and Third Assessment Reports, and National Research Council's endorsement of IPCC's work, the Bush Administration has moved toward outright abandonment of the Kyoto Process. ${ }^{178}$ This gradual movement has resulted in the United States' withdrawal from participation in the annual COP negotiations. ${ }^{179}$ During that time, the COP continued to refine the original Protocol, its implementation manuals, and moved toward establishing regulatory mechanisms for developing countries. ${ }^{180}$ Speaking to the Parties assembled in Bonn, Germany, U.S. Undersecretary for Global Affairs Paula J. Dobriansky announced that the United States continues to "be a constructive and active Party to the UN Framework Convention on Climate Change," adding that " $[t]$ hough the United States will not ratify the Kyoto Protocol, we will not abdicate our responsibilities." 181 At the COP-8 session, held at Marrakech, Morroco, in November 2001, the United States delegation "arrived at the conference with no new offers and largely stayed in the background while the talks proceeded haltingly." 182 By the COP-9 session, held at New Delhi, India, in November 2002 , the U.S. had moved its negotiating strategy away from Kyoto completely. ${ }^{183}$

176. Id. at 22. The scientists yielded that, "[b]ecause of uncertainty in climate sensitivity, and uncertainty about the geographic and seasonal patterns of projected changes in temperatures, precipitation, and other climate variables and phenomena, the impacts of climate change cannot be uniquely determined for individual emission scenarios." IPCC Third Report, supra note 40, at 22.

177. See id. IPCC yielded that "the benefits of different greenhouse gas emission reduction actions, including actions to stabilize greenhouse gas concentrations at selected levels, are incompletely characterized and cannot be compared directly to mitigation costs for the purpose of estimating the net economic effects of mitigation." Id.

178. See generally Kahn, supra note 133.

179. See id. at 552,553

180. See id. The United States sent delegations to both the July 2001 conference in Bonn, Germany, and the November 2001 conference in Marrakech, Morocco. Id.

181. Dobriansky Statement at Climate Change Meeting, U.S. Dept. of State, Int'l Info. Programs, July 19, 2001, available at http://usinfo.state.gov/topical/econ/group8/summit01 /wwwh01072002.html (last visited Mar. 25, 2004). The Undersecretary added that the United States would continue to "develop a science-based, technology-oriented, market-friendly basis to deal with climate change." Id. She said the United States seeks "an environmentally sound approach that would not hard the U.S. economy," and that it would not "limit artificially the ability of the private sector to participate or restrict unnecessarily the helpful role of carbon sequestration in dealing with climate change." Id.

182. Eric Pianin, 160 Nations Agree to a New Global Warming Treaty; U.S. Sits Out Morocco Talks; Pact Sets Mandatory Targets for Reducing Greenhouse Gas Emissions, WASHINGTON POST, Nov. 11, 2001, at A25.

183. See Kahn, supra note 133 , at 554 . 
At the close of COP-9, the parties enacted the Delhi Ministerial Declaration, which focused "on ways to help developing countries adapt to climate change," urged promotion of "technological advances through research and development," pushed for increased development of renewable energy resources, and promoted "the transfer of technologies that can help reduce greenhouse gas emissions." 184 Despite the advances, discussion at the conference distilled down to one conclusion-that the Kyoto Protocol must be ratified. ${ }^{185}$

The Bush Administration moved on to other climate change policy ideas. ${ }^{186}$ President Bush unveiled his "Clear Skies Initiative" in February 2002 , announcing his plan to urge voluntary power plant emissions reductions and to attain seventy percent reductions by $2018 .^{187} \mathrm{He}$ announced that "economic growth is key to environmental progress, because it is growth that provides the resources for investment in clean technologies." 188 The centerpiece of the Clear Skies Initiative is "a marketbased cap-and-trade approach," modeled on the sulfur dioxide/Acid Rain Program instituted by the Title IV of the Clean Air Act by way of the Clean Air Amendments of 1990, ${ }^{189}$ through which utilities can trade "pollution credits" among each other. ${ }^{190}$

However, legislation, like treaty ratification, is a function of the Congress. ${ }^{191}$ Congress's partisan divide has revealed fewer consensuses on the emerging issues of climate change than the Senate displayed when it resolved Byrd-Hagel. ${ }^{192}$ One issue that has revealed disagreement is the work of IPCC. ${ }^{193}$ Critics of the Kyoto Protocol and emissions reduction mechanisms have attacked IPCC for its inability to quantify the costs and benefits relative to emissions mitigation. ${ }^{194}$ Senator James Inhofe (R-Okla.),

184. Action to Reduce Impacts of Global Warming Urged, GLOBAL NEWS WIRE-ASIA AFRICA INTELLIGENCE WIRE, Nov. 12, 2002.

185. Id.

186. See President George W. Bush: Remarks Announcing the Clear Skies and Global Climate Change Initiatives in Silver Spring, Maryland, 38 Wk'ly Comp. Pres. Doc. 232 Feb. 14, 2002 [hereinafter Clear Skies Remarks].

187. See id.

188. Id. Such an approach would "harness the power of markets, the creativity of entrepreneurs, and draw upon the best scientific research." Id.

189. 42 U.S.C. $\$ \S 7651-7651(0)$ (1998). Under the Title IV Acid Rain Program, EPA allocates sulfur dioxide emission limits to all sources. 42 U.S.C. $\$ 7651 b$ (a). Sources that emit less than their allowed emission limits may trade or sell their excess amounts to other sources that cannot meet their own limits. 42 U.S.C. $\$ 7651 \mathrm{~b}(\mathrm{~b})$.

190. Clear Skies Remarks, supra note 186. President Bush lauded the Acid Rain Program, noting that the "cap-and-trade program ... has cut more air pollution ... in the last decade than all other programs under the 1990 Clean Air Act combined and by even more than the law required." Id.

191. See U.S. CONST. art. I, $\S 1$.

192. See Byrd-Hagel Resolution, S. Res. 98, 105th Cong., 143 CONG REC S8113-05 (1997) (enacted).

193. See, e.g., generally 149 CONG. REC. S10012-01 (2003).

194. See generally id. 
who chairs the U.S. Senate's Environment and Public Works Committee, chided IPCC and its three assessments before the Senate in July 2003. ${ }^{195}$ Senator Inhofe called the global warming debate "the greatest hoax ever perpetrated on the American people," and stated, "[ $t]$ here is no convincing scientific evidence that human release of carbon dioxide . . . or other greenhouse gases is causing or will, in the foreseeable future, cause catastrophic heating of the Earth's atmosphere and disruption of the Earth's climate." 196

While dramatic assertions such as those of Senator Inhofe exist in the debate, others in the Senate have pushed GHG reduction legislation despite their earlier endorsement of the Byrd-Hagel Resolution. ${ }^{197}$ The Senate entertained bi-partisan legislation in the 108th Congress designed to provide for scientific climate change research, "accelerate the reduction of greenhouse gas emissions . . by establishing a market-driven system of greenhouse gas tradeable allowances that could be used interchangeably with passenger vehicle fuel economy standard credits," reduce dependence on foreign oil, and ensure protection of consumers' interest. ${ }^{198}$ The bill targeted "emissions of global warming pollutants by electrical utilities, major industrial and commercial entities, and refiners of transportation fuels," and did so in a way "patterned after the highly successful market-based acid rain program of the Clean Air Act." 199 Bill co-author Senator Joseph Lieberman (D-Conn.) addressed the Senate one day before it went to a vote, and predicted, based on a Massachusetts Institute of Technology study, that the measure would cost American households less than $\$ 20$ annually. ${ }^{200} \mathrm{He}$ added that another study "calculated [that] every ton of pollutants needlessly emitted into our atmosphere costs Americans $\$ 160$, and we are currently emitting billions of

195. See generally id. Speaking before the Senate, Senator Inhofe called the IPCC's three assessments, "over time ... more and more alarmist" and dubbed the IPCC process akin to "a Soviet-style trial in which the facts are predetermined and ideological purity trumps technical and scientific examinations." Id. at S10016, S10017.

196. Id. at S10021 (quoting a statement by Dr. Frederick Seitz). Senator Inhofe added that American supporters of the Kyoto Protocol and carbon dioxide emissions reduction are motivated "not to solve environmental problems but to fuel their ever-growing fundraising machines, part of which are financed by the Federal taxpayers." Id. at $\$ 10022$.

197. See generally 149 CONG. REC. S13484-02 (2003) [hereinafter McCain-Lieberman Debate].

198. Id. The legislation was co-authored by Senator Joseph Lieberman (D-Conn.) and Senator John McCain (R-Ariz.), both of whom signed the Byrd-Hagel Resolution in 1998. See id. See also generally Byrd-Hagel Resolution, S. Res. 98, 105th Cong., 143 CONG REC S811305 (1997) (enacted).

199. McCain-Lieberman Debate, supra note 197, at S13486.

200. See id. at $\$ 13487$. 
tons each year." ${ }^{201}$ Moreover, Senator Lieberman ordered that the following be added to the record:

[I]n the time since we ratified the Rio Treaty, the United States, which produces more global warming emissions than any other nation, has not developed a serious program to respond to the threat that global climate change poses to the planet's environmental and economic health. As a result, U.S. emissions of global warming gases have grown steadily and now exceed 7 billion metric tons of $\mathrm{CO}_{2}$ equivalent gases-a growth of $14 \%$ from 1990 levels. ${ }^{202}$

The Senate rejected the proposal on October 30, 2003 by a fifty-five to forty-three vote. ${ }^{203}$ Despite the defeat, bill proponents lauded the vote as a victory. ${ }^{204}$ The measure drew "yea" votes by six Republicans and one independent in addition to the thirty-six Democrats. ${ }^{205}$ More importantly, supporters included Senators representing states with heavy coal production, automobile manufacturing and other industrial bases. ${ }^{206}$ Bill co-author Senator John McCain (R-Ariz.), encouraged by the vote, announced, "I want to assure my colleagues we will be back." 207 Nonetheless, the vote revealed a stark point regarding GHG emissions reduction - twelve years after signing the U.N. Framework Convention on Climate Change, the United States has not instituted any domestic effort to reduce greenhouse gas emissions. ${ }^{208}$ Furthermore, the United States has withdrawn from international negotiations on a workable solution to the global threat of climate change. ${ }^{209}$

201. Id. at $\$ 13488$. He summarized, "We are making a proposal that the MIT study says will cost every American family $\$ 20$ a year, compared to $\$ 150$ billion a year within 10 years globally." Id.

202. Id. at S13487 (quoting Bob Epstein and Nicole Lederer, of Environmental Engineers (E2)).

203. See Eric Pianin, Senate Rejects Mandatory Cap on Greenhouse Gas Emissions, WASH PosT, Oct. 31, 2033, at A4.

204. See id.

205. See id.

206. See id. The six Republicans included four from New England states: Sens. Lincoln Chafee (R-R.I.), Judd Gregg (R-N.H.), Olympia Snowe (R-Me.), Susan Collins (R-Me.), in addition to co-author Senator John McCain (R-Ariz.) and Vermont independent Senator James Jeffords (I-Vt.). See id. However, regulation proponents were particularly encouraged by the support of Indiana Sens. Richard Lugar (R-Ind.) and Evan Bayh (D-Ind.), as well as West Virginia Senator John D. Rockerfeller IV (D-W.V.), who faced strong lobbying opposition from coal producers. See Pianin, supra note 203. Likewise, supporters lauded favorable votes from Sens. Debbie Stabenow (D-Mich.) and Richard J. Durbin (D-Ill.), who turned against strong lobbying efforts from the automobile and other industries in their states. Id.

207. Id.

208. See McCain-Lieberman Debate, supra note 197, at S13487.

209. Id. 


\section{THE UNITED STATES' CleAN AIR ACT: AN OVERVIEW AND A FOCUS ON NAAQS}

When Congress enacted the Clean Air Act Amendments of 1970, it established that the federal government would set broad air pollution limits, which states would interpret into workable implementation plans (SIPs). ${ }^{210}$ This federalist model extends to the two pollution control approaches wrapped into the Act: the National Ambient Air Quality Standards (NAAQS) ${ }^{211}$ and the Hazardous Air Pollutants control standards. ${ }^{212}$ Under Section 108 of the Act, Congress charged the EPA Administrator to establish a list of air pollutants "reasonably . . . anticipated to endanger public health or welfare," created by "numerous or diverse mobile or stationary sources." 213

The U.S. Supreme Court has held that "[Section] 109(b)(1) and the NAAQS for which it provides are the engine that drives nearly all of Title I of the [Clean Air Act]." 114 Before reaching that section, the EPA must first identify the possible public health and welfare effects of the listed air pollutants, or "air quality criteria," based on the "latest scientific knowledge" 215 and publish "air pollution control techniques"216 in the Federal Register. ${ }^{217}$ Section 109 of the Act then requires the EPA to promulgate two sets of pollution standards, NAAQS, for each listed criteria pollutant. ${ }^{218}$ Primary NAAQS must reflect the pollution limits required to protect the public health, ${ }^{219}$ whereas secondary NAAQS must reflect the limits required to protect the public welfare. ${ }^{220}$ The duty then shifts to the states, which must

210. See generally 42 U.S.C. \$ 7401. (1995).

211. See 42 U.S.C. $\$ \S 7408-7410$.

212. See 42 U.S.C. $\$ 7412$.

213. 42 U.S.C. $\$ 7408(a)(1)(A)$,(B) (1995). Section 302 of the Act defines an air pollutant as "any air pollution agent or combination of such agents, including any physical, chemical, biological, radioactive (including source material, special nuclear material, and by product material) substance or matter which is emitted into or otherwise enters the ambient air." 42 U.S.C. $\$ 7602(\mathrm{~g})(1995)$. It adds that "[s]uch term includes any precursors to the formation of any air pollutant, to the extent the Administrator has identified such precursor or precursors for the particular purpose for which the term 'air pollutant' is used." Id. Effects on public welfare includes

but is not limited to, effects on soils, water, crops, vegetation, manmade materials, animals, wildlife, weather, visibility, and climate, damage to and deterioration of property, and hazards to transportation, as well as effects on economic values and on personal comfort and well-being, whether caused by transformation, conversion, or combination with other air pollutants.

42 U.S.C. \& 7602(h) (1995).

214. Whitman v. American Trucking Ass'ns., 531 U.S. 457, 468 (2001).

215. 42 U.S.C. $\$ 7408(a)(2)(1995)$.

216. 42 U.S.C. $\S 7408$ (d) (1995).

217. 42 U.S.C. \$ 7408(b)(1) (1995).

218. See 42 U.S.C. $\$ 7409$ (a) (1995).

219. See 42 U.S.C. $\$ 7409$ (b)(1) (1995).

220. See 42 U.S.C. $\$ 7409$ (b)(2) (1995). 
each adopt plans (SIPs) to establish area-specific emission control limits consistent with the NAAQS of each criteria pollutant. ${ }^{221}$

Congress intended for the criteria pollutant list to be dynamic rather than static. In the Clean Air Act Amendments of 1970, Congress directed the EPA to, "within 30 days after December 31, 1970, publish, and . . from time to time, thereafter revise, a list which includes each air pollutant ...."222

The Clean Air Act Amendments of 1970 gave the EPA no express direction, but the legislative history spurred the agency to list the first six criteria pollutants: carbon monoxide, sulfur dioxide, nitrogen dioxide, particulate matter, photochemical oxidants, and hydrocarbons. ${ }^{223}$ By design, the Act provides an opportunity for citizens to shape the development of the NAAQS through its citizen suit provision in Section 304(a)(2). ${ }^{224}$

Soon after courts were interpreting Congress's intent under the listing process, as private parties urged the listing of new pollutants on a range of jurisdictional theories. ${ }^{225}$ One court, for instance, held: "[W]hile the threshold decision to regulate under Sections $108-110$ is not precautionary but rather requires proof of demonstrable harm caused by the suspect pollutant, once the decision is made the standards promulgated must be preventative in nature."226 The EPA capped the first wave of challenges in 1978, when it promulgated NAAQS for lead-the first and last time the agency would act on pressure to add a new pollutant to the Section 108 list. ${ }^{227}$

221. See 42 U.S.C. $\$ 7410$ (1995).

222. 42 U.S.C. $\$ 7408(a)(1)$ (1995). Congress defines "air pollutant" as:

[A]ny air pollution agent or combination of agents, including any physical, chemical, biological, radioactive ... substance or matter which is emitted into or otherwise enters the ambient air ... includ[ing] any precursors to the formation of any air pollutant, to the extent the Administrator has identified such precursor or precursors ....

42 U.S.C. $\$ 7602(\mathrm{~g})(1995)$.

EPA defined "ambient air" as "the portion of the atmosphere, external to buildings, to which the general public has access." 40 C.F.R. $\$ 50.1$ (2003).

223. See Natural Res. Def. Council, Inc. v. Train, 545 F.2d 320, 325, 326, 327 (citing Legislative History, Clean Air Act Amendments, Vol. 1). See also 36 Fed. Reg. 22384 (1971). Original proposed NAAQS for carbon monoxide. Id. See also National Primary and Secondary Ambient Air Quality Standards, 48 Fed. Reg. 628 (1983). EPA later decided to re-designate the photochemical oxidants and hydrocarbons criteria as ozone. Id.

224. 42 U.S.C. $\$ 7604(a)(2)(1995)$. Section 304(a)(2) of the Clean Air Act provides that "any person may commence a civil action on his own behalf ... against the Administrator where there is alleged failure of the Administrator to perform any act or duty under this chapter which is not discretionary with the Administrator...." Id.

225. See Natural Resources Defense Council, Inc. v. Train, 411 F. Supp. 864, 866 (S.D.N.Y. 1976). "Plaintiffs have alleged four separate grounds upon which the court might find jurisdiction: 1) $\S 304$ of the Clean Air Act . . . 2) the Administrative Procedures Act, 5 U.S.C. $\S \S 701-706 ; 3)$ the Declaratory Judgment Act, 28 U.S.C. $\S \S 2201-2$; and 4) the mandamus provisions of 28 U.S.C. $\S 1361$." Id.

226. Ethyl Corp. v. EPA, 541 F.2d 1, 15 (D.C. Cir. 1976).

227. See 43 Fed. Reg. 46258 (Oct. 5, 1978). 
IV. FORCED PROMULGATION OF NAAQS FOR LEAD: NATURAL RESOURCES DEFENSE COUNCIL V. TRAIN

Pressure on the EPA to promulgate air quality criteria and NAAQS for lead, as indicated, arrived through the courts. In Natural Resources Defense Council $v$. Train, a group of environmental plaintiffs sought to compel the EPA to list lead as a pollutant under Section $108 .{ }^{228}$ Plaintiffs claimed standing under four theories, ${ }^{229}$ including that of Section 304 of the Act, which permits citizen-initiated actions against the EPA Administrator for failure to perform a non-discretionary duty under the Act. ${ }^{230}$ Plaintiffs claimed that the Administrator's failure to list lead as a pollutant, in the face of acknowledged science and the state of the law, satisfied the breach of a non-discretionary duty requirement. ${ }^{231}$ They maintained that

the statutory language, legislative history and purpose, as well as current administrative interpretation of the 1970 Clean Air Act, all militate in favor of finding that the Administrator's function to list pollutants under $\S 108$ is mandatory, once it is determined by the Administrator that a pollutant 'has an adverse effect on public health or welfare' and comes from the requisite numerous and diverse sources. ${ }^{232}$

The EPA conceded that lead pollution met elements (A) and (B) of Section 108(a)(1), ${ }^{233}$ but countered that it must still have listing discretion because the Clean Air Act provides "alternative remedies provided in various sections" and because "any decision to utilize the remedies provided by [Sections] 108-110 involves complex considerations." ${ }^{\text {"234 }}$

Judge Charles E. Stewart Jr. of the U. S. District Court for the Southern District of New York, ruled for the plaintiffs, holding:

There is no language anywhere in the statute which indicates that the Administrator has discretion to choose among the remedies which the Act provides. Rather, the language of [Section] 108 indicates that upon certain enumerated conditions, one factual and one judgmental, the Administrator 'shall' list a pollutant which triggers the remedial provisions

228. See Train, 411 F. Supp. at 864 .

229. Id.

230. Id. at 866. See also, 42 U.S.C. § 7604(a) (1995).

231. See Train, 411 F. Supp at 867.

232. Id.

233. See id. See also, 42 U.S.C. \$§ 7408-7410.

234. Train, 411 F. Supp at 867 (quoting Defendants' Brief at 22). 
of [Sections] 108-110. The statute does not provide, as defendants would have it, that the Administrator has authority to determine whether the statutory remedies which follow a [Section] 108 listing are appropriate for a given pollutant. ${ }^{235}$

Judge Stewart found additional support for plaintiffs' position in the Senate Committee Report for the 1970 amendments, holding that Section 108(a)(1)(C) applied only to the initial list promulgated by the EPA. ${ }^{236}$ Judge Stewart found that the "clear legislative intent to have strict mandatory health procedures in effect by mid-1976" could not comport with the defendant's reading of Section 108. ${ }^{237} \mathrm{He}$ added, "the phrase ['for which he plans to issue air quality criteria'] cannot mean that the Administrator need not list pollutants which meet the two requisites clearly set forth in the section."238 Instead, the judge found:

While the Administrator is provided with much discretion to make the threshold determination of whether a pollutant has 'an adverse effect on health,' after that a decision is made, and after it is determined that a pollutant comes from the necessary sources, there is no discretion provided by the statute not to list the pollutant. ${ }^{239}$

The EPA's decision to regulate the pollutant under a different section of the Act did not relieve the Administrator of the duty to list the pollutant under Section 108, Judge Stewart held. ${ }^{240}$ Finally, he undercut the EPA's defense that it need not list a pollutant where "the data which would be necessary to support an ambient air standard for lead is arguably lacking: ${ }^{241}$

We do not think that the potential lack of data would have been an appropriate consideration prior to listing a pollutant under [Section] 108 in any event. Under the statutory scheme, the listing of a pollutant is not more than a threshold to the remedial provisions. . . . Once he has [crossed that threshold], the Administrator does not have the discretion not

235. Id. at 868.

236. See id.

237. Id.

238. Id.

239. Id

240. See Train, 411 F. Supp at 870. "Despite regulation under [Section] 211, however, the Administrator must nevertheless list lead as a pollutant since it concededly meets the two criteria of [Section] $108 \ldots$... Id. 
to list lead as a pollutant because necessary data-data other than that necessary to make the initial decision as to 'adverse effect' -is unavailable. The statute appears to assume that, for each pollutant which must be listed, criteria and a national standard can be established. ${ }^{242}$

The U.S. Court of Appeals for the Second Circuit affirmed the district court, finding that "the interpretation of the Clean Air Act advanced by the EPA is contrary to the structure of the Act as a whole, and . . would vitiate the public policy underlying the enactment of the 1970 Amendments as set forth in the Act and its legislative history."243 The court mandated the EPA's listing of lead, holding that the Act, "its legislative history, and the judicial gloss placed upon the Act leave no room for an interpretation which makes the issuance of air quality standards for lead under [Section] 108 discretionary. The Congress sought to eliminate, not perpetuate, opportunity for administrative foot-dragging." 244

\section{NORTHEAST STATES' LAWSUITS: SEEKING TO MANDATE REGULATION OF CARBON DIOXIDE THROUGH THE COURTS}

A coalition of citizens' groups, acting under Section 304 of the Act, spurred the drive that resulted in the EPA's promulgation of the lead NAAQS. $^{245}$ In 2003, a group of states set out to use the same process to compel the EPA's regulation of carbon dioxide emissions on one front, and a different section of the Clean Air Act to accomplish the same goal from another. ${ }^{246}$

On October 23, 2003, eleven states, the District of Columbia and American Samoa filed two petitions for review before the U. S. Court of Appeals for the District of Columbia Circuit. ${ }^{247}$ The first petition seeks review

242. Id.

243. See Train, 545 F.2d at 324.

244. $l d$. at 328.

245. See Train, 411 F. Supp. at 866. See also 42 U.S.C. $\$ 7604$ (1995). Section 304(a)(2) of the Clean Air Act provides that "any person may commence a civil action on his own behalf ... against the Administrator where there is alleged failure of the Administrator to perform any act or duty under this chapter which is not discretionary with the Administrator ...." 42 U.S.C. $\S 7604(a)(2)$.

246. See generally Complaint, Commonwealth of Mass., et al., v. EPA, U.S. Dist. Ct. (D. Conn. June 4, 2003) (No. 3:03-CV-984-PCD) (on file with author) [hereinafter Complaint]. Maine and Connecticut were also parties to the initial suit. Id. See also generally Petition for Rulemaking and Collateral Relief Seeking the Regulation of Greenhouse Gas Emissions from New Motor Vehicles under $\S 202$ of the Clean Air Act, International Ctr. for Tech. Assessment v. EPA, (Oct. 20, 1999) (on file with author) [hereinafter Citizens' Petition].

247. See Petition for Review, Commonwealth of Mass. v. U.S. EPA, Docket No. 03-1365 (Oct. 23, 2003) (on file with author) [hereinafter $\$ 108$ Appeal]. See also Petition for Review, Commonwealth of Mass. v. U.S. EPA, Docket No. 03-1361 (Oct. 23, 2003) (on file with author) 
of an August 28, 2003 "final agency action," 248 consisting of a memorandum issued by EPA General Counsel Robert E. Fabricant to the agency's Acting Administrator Marianne L. Horinko. ${ }^{249}$ The memorandum dispelled any recognition of the agency's capacity to regulate carbon dioxide as a pollutant under the Clean Air Act, and formally withdrew the April 10, 1998 memorandum of former General Counsel Jonathan Z. Cannon "as no longer representing the views of EPA's General Counsel."250

The states' second petition seeks review of a different final agency action which the EPA undertook on August 28, 2003, when it denied a citizens' petition for rulemaking which "sought regulation of emissions of greenhouse gases (including carbon dioxide, methane, nitrous oxide, and hydrofluorocarbons) from new motor vehicles and engines pursuant to Section $202^{251}$ of the Clean Air Act." ${ }^{252}$ On August 28, 2003, the EPA denied the petition, under which a coalition of environmental groups led by the International Center for Technology Assessment and the Sierra Club, pushed the agency to "undertake the ... mandatory duties" to regulate the four greenhouse gases under Section 202(a)(1) of the Act. ${ }^{253}$ Asserting their rights

[hereinafter $\$ 202$ Appeal]. The other ten states are Connecticut, Maine, Illinois, New Jersey, New Mexico, New York, Oregon, Rhode Island, Vermont, and Washington. Id.

248. One of their causes of action rests on their right to challenge "final agency actions," as provided by the Administrative Procedures Act. 5 U.S.C. $\$ \$ 701-706$ (1998). An “"agency action' includes the whole or a part of an agency rule, order, license, sanction, relief, or the equivalent or denial thereof, or failure to act." 5 U.S.C. \$ 551(13).

249. See $§ 108$ Appeal, supra note 247.

250. Memorandum from Robert E. Fabricant, General Counsel, to Marianne L. Horinko, Environmental Protection Agency Acting Administrator (Aug. 28, 2003), available at http://www.epa.gov/airlinks/co2_general_counsel_opinion.pdf (last visited Mar. 29, 2004) [hereinafter Fabricant Memorandum]. See also generally Cannon Memorandum, supra note 145.

251. 42 U.S.C. $\$ 7521$. Section 202 grants to EPA the authority to "prescribe ... standards applicable to the emission of any air pollutant from any class or classes of new motor vehicles or new motor vehicle engines, which in [its] judgment cause, or contribute to, air pollution which may reasonably be anticipated to endanger public health or welfare." 42 U.S.C. $\S$ 7521(a)(1).

252. § 202 Appeal, supra note 247.

253. Citizens' Petition, supra note 246, at 2. See also Control of Emissions from New Highway Vehicles and Engines, Notice of denial of petition for rulemaking, 68 Fed. Reg. 52922 (2003) [hereinafter $\$ 202$ Petition Denial]. The original group of petitioners filed its own appeal of EPA's refusal to initiate rulemaking for carbon dioxide, methane, nitrous oxide, and hydrofluorocarbons under Section 202 on Oct. 23, 2003. Petition for Review, International Ctr. for Tech. Assessment v. U.S. EPA, Docket No. 03-1363 (Oct. 23, 2003). The same group issued a separate "final agency action" challenge of the propriety of the Fabricant Memorandum. Petition for Review, International Ctr. for Tech. Assessment v. U.S. EPA, Docket No. 03-1367 (Oct. 23, 2003). 
as aggrieved parties under the Administrative Procedures Act, ${ }^{254}$ the States seek review of the EPA's denial of the citizens' petition. ${ }^{255}$

\section{A. The Section 108 Challenge}

The Attorneys General of Massachusetts, Connecticut, and Maine initially filed notice of intent to sue the EPA on January 30, 2003, announcing their aim to force the EPA into listing carbon dioxide as a criteria pollutant pursuant to Section $108 .^{256}$ The notice indicated the states' intent to proceed with a lawsuit against the Agency after the close of the sixty-day notice period proscribed by Section 304.257

The States contended that the EPA has "a mandatory duty under existing law to begin to regulate carbon dioxide as a 'criteria air pollutant' . . ."258 The states based this claim on two points: the EPA has acknowledged that carbon dioxide is an "air pollutant," under Section 302(g), ${ }^{259}$ and the EPA has further recognized that carbon dioxide meets both elements of Section

254. See 5 U.S.C. $\$ 702$ (1998). The section provides "[a] person suffering legal wrong because of agency action, or adversely affected or aggrieved by agency action within the meaning of a relevant statute, is entitled to judicial review thereof." Id.

255. § 202 Appeal, supra note 247.

256. Notice of Intent to Sue Under Clean Air Act $\$ 7604$, Commonwealth of Mass. v. EPA, Jan. 30, 2003 [hereinafter Jan. Notice], at 2. On Feb. 20, 2003, the States announced a second set of grounds for injunctive relief. Notice of Intent to Sue Under Clean Air Act $\$ 304(b)(2)$, State of New York v. EPA, Feb. 20, 2003 [hereinafter Feb. Notice]. The Feb. 22 claims centered on EPA's "failure to review, and if appropriate, revise the New Source Performance Standards (NSPS) for fossil fuel fired electrical generating units . . found at 40 CFR subpart Da." Id. The cited regulation sets out the emission caps for fossil fuel generating power plants with respect to particulate matter, sulfur dioxide, and nitrogen oxides. 40 C.F.R. $\$ 60.41$ (a) (2003). EPA must, "at least every 8 years, review and, if appropriate, revise such standards following the procedure required by this subsection ..." 42 U.S.C. $\S 7411$ (b)(1)(B) (1995). The States sought to compel EPA to revise the existing standards for sulfur dioxide and particulates, contending that the standards "fail to reflect the technological advances that have occurred in the past two decades as well as the current information regarding the environmental harm posed by those pollutants." Feb. Notice, supra note 256 , at 1,2 . The States further asserted "that subpart $\mathrm{Da}$ is inadequate in that it does not contain a standard for emissions of carbon dioxide, a pollutant that causes global warming with its attendant adverse health and environmental impacts." Id. at 2. While the Feb. Notice clearly laid out the States' potential course of action, they did not proceed with the claims under Section 304(b)(2) when they filed the Complaint later that summer. See generally Complaint, supra note 246.

257. Feb. Notice, supra note 256, at 1 . Section 304(b) sets forth that "no action may be commenced ... prior to 60 days after the plaintiff has given notice of such violation to the Administrator." 42 U.S.C. $\S 7604$ (b)(1)(B) (1995).

258. Jan. Notice, supra note 256 , at 2 .

259. Id. Section 302 defines an air pollutant as "any air pollution agent or combination of agents ... which is emitted into or otherwise enters the ambient air," including "any precursors to the formation of any air pollutant" identified by the EPA as relevant to establishing an agent as an air pollutant. 42 U.S.C. $\$ 7602(\mathrm{~g})$. 
108(a). ${ }^{260}$ With respect to Section $108(a)(1)(A)$, the notice claimed that "there is no longer any genuine dispute that carbon dioxide emissions are endangering public health or welfare ... [considering that] Section 302(h) of the Act defines 'welfare' to include effects on 'weather' and 'climate.",261 The notice also pointed to a U.S. government document, ${ }^{262}$ which "details many specific examples of adverse impacts to weather and public health that are occurring ... and health effects due to air pollution and extreme weather events." ${ }^{263}$ It further contended that "it is an indisputable fact that carbon dioxide emissions 'result from numerous or diverse mobile or stationary sources,' including power plants, industrial sources and motor vehicles."264 The states concluded that:

Climate change attributable to carbon dioxide emissions will have dramatic effects for the quality and nature of life in the northeast .... Suffice it to say that carbon dioxide emissions will likely cause or contribute to wide-ranging, adverse changes to just about every aspect of the environment, public health and welfare throughout the northeast. ${ }^{265}$

Massachusetts, Maine, and Connecticut filed suit in the U.S. District Court for the District of Connecticut on, June 4, 2003. ${ }^{266}$ The complaint rested on a single cause of action-the EPA's "Failure to Perform a Nondiscretionary Duty Pursuant to CAA $\S 304(a)(2) . " 267$ The parties argued that the EPA's failure to list carbon dioxide as a criteria pollutant

260. Id. Section 108 charges the EPA to establish a list of air pollutants "reasonably ... anticipated to endanger public health or welfare," created by "numerous or diverse mobile or stationary sources." 42 U.S.C. $\& 7408(a)(1)(A),(B)$.

261. Jan. Notice, supra note 256 , at 3.

262. U.S. Climate Action Report - 2002, U.S. Dept. of State, Washington, D.C., May 2002, available at http://unfccc.int/resource/docs/natc/usnc3.pdf (last visited Mar. 29, 2004) [hereinafter Climate Action Report]. This report served as the United States' third National communication to the COP, as required by the terms of the U.N. Framework Convention on Climate Change. See id. at 4.

263. Jan. Notice, supra note 256 , at 3.

264. Id. at 4; see also 42 U.S.C. $\S 7408(\mathrm{a})(1)(\mathrm{B})$ (1995).

265. Jan. Notice, supra note 256 , at 6.

266. Complaint, supra note 246.

267. Id. at 29. The claim mirrored the analysis laid out in the Jan. Notice. Id. I114-123. See also Jan. Notice, supra note 256. It recognized that carbon dioxide meets the definition of "air pollutant," as established by "Section 302(g) of the Act, 42 U.S.C. \$ 7602(g)." Complaint, supra note 246 115-17. It further stated that the both stationary and mobile sources produce the gas, as required by Sections $108(\mathrm{a})(1)(B)$ and 302 (z) of the Act, 42 U.S.C. $\$ \S 7408(a)(1)(B)$, 7602(z). Id. \1119-21. "By failing to revise the list of air pollutants under Section 108(a)(1) of the Act, 42 U.S.C. $\$ 7408(a)(1)$, to include carbon dioxide," the complaint announced, "the Administrator has failed to perform a nondiscretionary duty within the meaning of Section 304(a)(2) of the Act, 42 U.S.C. § 7604(a)(2)." Id. I122. 
is unlawfully increasing the likelihood of harming the economic interests of the Plaintiff States, is unlawfully increasing the likelihood and severity of damage to property owned by each of the Plaintiff States, is unlawfully denying residents of each of the Plaintiff States the benefits due them under the federal Clean Air Act, and is unlawfully subjecting residents of each of the Plaintiff States to increased risks of harm to human health, welfare, and general economy that are associated with the continued unregulated emissions of carbon dioxide. ${ }^{268}$

The complaint alleged that the EPA recognized carbon dioxide's status as a pollutant, "on at least three occasions," during the Clinton Administration. ${ }^{269}$ Further, the complaint alleged that President Bush's EPA "made a judgment that emissions of carbon dioxide cause or contribute to air pollution which may reasonably be anticipated to endanger public health or welfare within the meaning of Section $108(\mathrm{a})(1)(A)$ of the Act, 42 U.S.C. $\S 7408(\mathrm{a})(1)(\mathrm{A}) .{ }^{270}$ Moreover, the States alleged that the EPA, under the

268. Id. 1123 . The States alleged a range of harm they each continued to suffer as a result of EPA's failure to regulate carbon dioxide. Id. \$T65-107. The complaint listed harms by type-public health, coastal resources, water resources, agricultural resources, and forest resources. Id. For instance, the complaint estimated that "[b]y 2100 , precipitation in Massachusetts [will] increase by about $10 \%$ in spring and summer, $15 \%$ in fall, and $20-60 \%$ in winter." Complaint, supra note 246 I68. It added that public health would suffer, for instance, where a "projected [two degree Fahrenheit] warming could increase heat-related deaths in Hartford [Connecticut] during a typical summer by about $20 \%$, from close to 40 heatrelated deaths per summer to near 50." Id. $\mathbb{1 7 1}$. It predicted that Massachusetts' coastal resources would be harmed, whereby "[s]ea level rise will likely inundate coastal wetlands, destroying habitat for commercial and game species as well as migratory birds and other wildlife." Id. \$84. It further alleged Connecticut's water resources would be harmed, for instance, because "the Connecticut River is susceptible to changes in winter snow accumulation, which would be reduced in a warmer climate." Id. 194. It also predicted that Maine's agricultural resources would be harmed: "[g]lobal warming will likely reduce potato yields" and "[h]ay and pasture yields will likely decrease considerably as temperatures rise beyond the tolerance level of the crop." Id. \$99. It also alleged that Maine's forest resources will suffer harm, where "[t]he already high threat of insect pest outbreaks in the northern forest will likely be exacerbated by warming-induced changes in the timing of spring frosts." Id. I105.

269. Complaint, supra note $246 \$ 32,33-36$. The States pointed to former EPA Administrator Browner's statement to Rep. Thomas DeLay (R-Tex.) that the Clean Air provided authority to regulate carbon dioxide, and former EPA General Counsel Cannon's affirmation of that opinion in his April 10, 1998 memorandum. Id. $\mathbb{1 3 3}, 34$. See also Cannon Memorandum, supra note 145. The States also pointed to former EPA General Counsel Guzy's Oct. 6, 1999 testimony before Congress. Complaint, supra note 246, \$35. See also Guzy Testimony, supra note 152.

270. Complaint, supra note $246 \$ 118$. The States pointed to a speech given by former EPA Administrator Christine Todd Whitman before the G8 Environmental Ministerial Meeting Working Session on Climate Change in Trieste, Italy, on March 3, 2001. Id. \$36. The States alleged that Administrator Whitman "made a judgment under Section 108(a)(1)(A)" when she told the assembly: 
Bush Administration, acknowledged carbon dioxide's status as a pollutant through its preparation and presentation of the United States' Third National Communication to the COP, pursuant to the U.N. Framework Convention on Climate Change. ${ }^{271}$ The complaint highlighted the document's projected public health or welfare impacts of carbon dioxide-induced climate change. ${ }^{272}$ It also noted the agency's documented acceptance and understanding of climate change threats, which undermined the Administration's basis for refusing to initiate rulemaking for carbon dioxide emissions reduction. ${ }^{273}$ The States asked the Court to "[o]rder the Administrator to revise the list of air pollutants pursuant to Section 108(a)(1) of the Act, 42 U.S.C. § 7408(a)(1), to include carbon dioxide."274

On September 3, 2003 the States withdrew their lawsuit in the Connecticut court. ${ }^{275}$ In response to General Counsel Fabricant's August 28, 2003 memorandum, ${ }^{276}$ which officially withdrew EPA recognition of carbon dioxide's status as an air pollutant under the Clean Air Act, the States terminated their suit and packaged the substance of their Section 108 claims into a challenge before the U.S. Court of Appeals for the District of Columbia Circuit. ${ }^{277}$ To proceed with their argument that the EPA had acknowledged carbon dioxide as an air pollutant, reasonably anticipated to endanger public health within the meaning of the Act, the States recognized the need to attack the propriety of the Fabricant Memorandum. ${ }^{278}$ The States have proceeded with that attack by challenging the Fabricant Memorandum as an impermissible final agency action in the Court of Appeals. ${ }^{279}$

Increasingly, there is little room for doubt that humans are affecting the Earth's climate, that the climate change we've seen during the past century is the result of human activity, and that we must continue our efforts to stop and reverse the growth in the emission of greenhouse gases. If we fail to take the steps necessary to address the very real concern of global climate change, we put our people, our economies, and our way of life at risk.

Id.

271. Id. .433.

272. Id. $\llbracket 57$

273. Id. $\llbracket 58$.

274. Complaint, supra note 246, at 31 . The Complaint's Prayer for Relief also included requests to "[a]ward the Plaintiff States their costs of this action and attorneys' fees," and to "[g]rant such other relief as the Court deem[ed] just and proper." Id.

275. Telephone interview with Gerald D. Reid, Assistant Attorney General, Dept. of the Attorney General, State of Maine (Oct. 22, 2003) (on file with author) [hereinafter Reid Interview].

276. See Fabricant Memorandum, supra note 250.

277. See Reid Interview, supra note 275. See also $\$ 108$ Appeal, supra note 247. Because it officially withdrew the Cannon Memorandum as an official EPA opinion, the Fabricant Memorandum arguably stripped the States of their evidentiary foundation. See Fabricant Memorandum, supra note 250.

278. See Reid Interview, supra note 275.

279. See § 108 Appeal, supra note 247. 


\section{B. The Section 202 Challenge}

The States are also challenging the EPA's denial of a petition to initiate rulemaking under Section 202 of the Clean Air Act filed by a coalition of citizens' groups (Coalition). ${ }^{280}$ As of February 2004, the States had not filed briefs in support of their Petition for Review under Section 202, but they will do so pursuant to their standing conferred by the Administrative Procedures $\mathrm{Act}^{281}$ as parties aggrieved by a final agency action. ${ }^{282}$

On October 20,1999, the Coalition asked the EPA to "undertake her mandatory duty to regulate these as directed by \$202(a)(1) of the [Clean Air Act]." 283 The Petition noted that the EPA had recognized carbon dioxide emissions to be an "air pollutant," "emitted from new motor vehicles," and that "the emission causes or contributes to air pollution which may reasonably be anticipated to endanger public health or welfare," thereby compelling regulation under Section 202. ${ }^{284}$ The Petition stated that the language in Section 202(a) establishes a mandatory duty, due to Congress's use of "shall" in its charge to the EPA. ${ }^{285}$ The Coalition added that, "even should the agency believe that there are scientific uncertainties regarding the actual impacts from global warming, the precautionary purpose of the [Act] supports actions regulating . . . these gases." 286

The EPA rejected the petition on September 8, 2003, "conclud[ing] that it cannot and should not regulate GHG emissions from U.S. motor vehicles under the [Clean Air Act]." 287 In support of its decision, the EPA announced:

280. See $\S 202$ Appeal, supra note 247; see also Citizens' Petition, supra note 246.

281. 5 U.S.C. $\$ 702$ (1998).

282. See $\$ 202$ Appeal, supra note 247.

283. Citizens' Petition, supra note 246, at 9.

284. Id. The Coalition recognized that "mobile sources emit significant amounts of $\mathrm{CO}_{2}$," and that " $[\mathrm{t}]$ he transportation sector contributes over $30 \%$ of U.S. greenhouse gas $\mathrm{CO}_{2}$ emissions from fossil fuel combustion," and that "[a]lmost two-thirds of the emissions come from automobiles and the remaining emissions ... from transportation sources are predicted to grow faster than any other emission source." Id. at 10 . The Coalition relied on the Cannon Memorandum in support of its assertion that carbon dioxide met the air pollutant definition. Id. It submitted that carbon dioxide, by contributing to global warming endangers public health by "increase[ing] the threat of infectious diseases"; directly affecting human health due to heat stress, increases in cancer rates, cataracts, and immune suppression. Id. at 15, 16, 18, 19. The Coalition then submitted that carbon dioxide would endanger public welfare by harming the several elements of the environment and by affecting human welfare in indirect ways. Id. at 20 , 21-23, 24-26.

285. Id. at 29. Section 202(a) states that EPA "shall by regulation prescribe ... standards applicable to any air pollutant from any ... class or classes of new motor vehicles." 42 U.S.C. $\S 7521$ (a)

286. Citizens' Petition, supra note 246, at 29. The Petition urged that EPA need not await conclusive scientific proof of adverse health effects where reasonable inferences can be drawn in support of such effects. See id. See also Ethyl Corp. v. EPA, 541 F.2d 1, 15 (D.C. Cir. 1976).

287. § 202 Petition Denial, supra note 253, at 52925. 
Based on a thorough review of the [Clean Air Act], its legislative history, and other congressional action and Supreme Court precedent, EPA believes that the [Act] does not authorize regulation to address global climate change. Moreover, even if $\mathrm{CO}_{2}$ were an air pollutant generally subject to regulation under the [Act], Congress has not authorized the Agency to regulate $\mathrm{CO}_{2}$ emissions from motor vehicles to the extent such standards would effectively regulate car and light truck fuel economy, which is governed by a comprehensive statute $^{288}$ administered by [the U.S. Department of Transportation]. ${ }^{289}$

The EPA clarified this stance, announcing that it "does not have authority to regulate motor vehicle emissions of $\mathrm{CO}_{2}$ and other GHGs under the [Clean Air Act]." 290 While it denied the Coalition's petition, the EPA

288. See Energy Policy and Conservation Act, 42 U.S.C. $\$ \S 6231-6246$ (1998). This act assigned rulemaking authority over vehicular fuel economy to the U.S. Dept. of Transportation. Id.

289. $\$ 202$ Petition Denial, supra note 253, at 52925. EPA relied on guidance the U.S. Supreme Court's provided in its 2000 case, Food and Drug Admin. v. Brown \& Williamson Tobacco Corp., 529 U.S. 120 (2000). In that case, the Court was "obliged to defer not to [FDA's] expansive construction of [a] statute," in which the agency elected to regulate tobacco as a drug, "but to Congress' consistent judgment to deny the FDA this power." Id. at 160. Justice Sandra Day O'Connor wrote that judicial deference to agency actions, "premised on the theory that a statute's ambiguity constitutes an implicit delegation from Congress to the agency to fill in the statutory gaps," must have limits. Id. Justice O'Connor highlighted the particular need for limits in "extraordinary cases," where "there may be reason to hesitate before concluding that Congress has intended such an implicit delegation." Id. EPA analogized Congress's reluctance to authorize regulation of carbon dioxide to the "extraordinary case" of FDA's attempt to regulate tobacco absent specific authorization from Congress. See $\S 202$ Petition Denial, supra note 253, at 52925-28. It announced, "[a]gainst this backdrop of consistent congressional action to learn more about the global climate change issue before specifically authorizing regulation to address it, the [Clean Air Act] cannot be interpreted to authorize such regulation in the absence of any direct or even indirect indication of congressional intent to provide such authority." Id. at 52928. EPA concluded:

In light of Congress' attention to the issue of global climate change, and the absence of any direct or even indirect indication that Congress intended to authorize regulation under the [Act] to address global climate change, it is unreasonable to conclude that the [Act] provides the Agency with such authority. An administrative agency properly awaits congressional direction before addressing a fundamental policy issue such as global climate change, instead of searching for authority in an existing statute that was not designed or enacted to deal with the issue. We thus conclude that the [Act] does not authorize regulation to address concerns about global climate change.

Id. at 52928.

290. Id. at 52929. It added that the provision in Section 202 "authorizing regulation of motor vehicle emissions does not impose a mandatory duty on the Administrator to exercise her judgment," rather it "provides the Administrator with discretionary authority to address 
yielded that it would continue to follow President Bush's policy of pursuing "near-term voluntary actions and incentives along with programs aimed at reducing scientific uncertainties and encouraging technological development so that the government may effectively and efficiently address the climate change issue over the long term."291

The Coalition will likely center the Section 202 appeal on its initial claim that the EPA shirked its mandatory duty to regulate carbon dioxide emissions. ${ }^{292}$ The States, however, are likely to proceed with a different argument against the petition denial-that the EPA's statement that it lacks authority under the Clean Air Act is legally untrue, and that "the lack of authority reasoning is not valid law." ${ }^{293}$ Briefs in support of the petition for review should be forthcoming by June $1,2004 .^{294}$

\section{The Claims' Likelihood of Success}

While the arguments supporting both sets of future carbon dioxide requirements appear to be the same, some commentators suggest that procedure-based claims like those in the Section 202 appeal are more likely to succeed than those "concerning the substance of environmental laws."295 As one legal scholar noted, "The underlying legal arguments have a lot of problems because they assume the E.P.A. has the authority and the obligation to dramatically expand the regulation of emissions without Congressional approval."296 The Senate's present unwillingness to act on international carbon dioxide reduction initiatives lends support to this tactical attitude. ${ }^{297}$ Another comment suggests that "Congress can most effectively regulate the

emissions." Id. EPA responded to the Coalition's reliance on the mandatory statutory language of Section 202:

While [S]ection 202(a)(1) uses the word 'shall,' it does not require the Administrator to act by a specified deadline and it conditions authority to act on a discretionary exercise of the Administrator's judgment regarding whether motor vehicle emissions cause or contribute to air pollution that may reasonably be anticipated to endanger public health or welfare.

Id.

291. See $§ 202$ Petition Denial, supra note 253, at 52930. EPA noted, "[b]y contrast, establishing GHG emission standards for U.S. motor vehicles at this time would require EPA to make scientific and technical judgments without the benefit of the studies being developed to reduce uncertainties and advance technologies." Id. at 52931. It added that it "would decline the petitioners' request to regulate motor vehicle GHG emission even if it had authority to promulgate such regulations." Id.

292. See Reid Interview, supra note 275.

293. Id.

294. Id.

295. Jennifer 8. Lee, 7 States to Sue E.P.A. Over Standards on Air Pollution, N.Y. TIMES, Feb. 21, 2003, at A25.

296. Id.

297. See Bugnion \& Reiner, supra note 13, at 525. 
causes of climate change by amending the Clean Air Act," much as it did with acid rain and ozone in the 1990 amendments. ${ }^{298}$

However, the strict language of Section 108 and the District of Columbia Circuit's ruling in Train leave little justification for courts to avoid compelling the EPA to list carbon dioxide as a criteria pollutant. ${ }^{299}$ To issue a writ of mandamus pursuant to either the Section 109 or the Section 202 challenge, a court must find that the States' evidence shows: (a) the EPA has deemed carbon dioxide an air pollutant, under Section 302(g); (b) climate change threatens either public health or public welfare; and (c) carbon dioxide is emitted by numerous or diverse, mobile or stationary sources. ${ }^{300}$ Moreover, the court must make these findings in light of the language in Section 111, which urges the Administrator to use "his judgment" to determine if a pollutant "may reasonably be anticipated to endanger public health or welfare."301

The States face a difficult challenge in their effort to force the EPA to institute motor vehicle emissions standards for carbon dioxide under Section 202, and could easily lose the war if a court defers to the EPA's discretion to keep carbon dioxide out of the new regulations. ${ }^{302}$ Petitioners challenging an agency's action or inaction, must satisfy the test laid out by the U.S. Supreme Court in Chevron U.S.A. Inc. v. Natural Resources Defense Council, Inc. ${ }^{303}$ To succeed under Chevron, petitioners must show that an agency impermissibly interpreted an ambiguous statute. ${ }^{304}$ However, the Court later clarified that "[d]eference under Chevron ... is premised on the theory that a statute's ambiguity constitutes an implicit delegation from Congress to the agency to fill in the statutory gaps." 305

The U.S. Supreme Court has held that regulation of "an industry [that] constitut[es] a significant portion of the American economy" may require more from Congress than an ambiguous delegation of authority, from which an agency may initiate rulemaking-especially where Congress has "created a distinct regulatory scheme," and has "repeatedly acted to preclude any

298. Id. The authors suggest this is so because "the evidence of [carbon dioxide's] impacts on public health or on other living things, which would justify establishing either a primary NAAQS standard or a hazardous air pollutant standard, is weak and speculative." Id.

299. See 42 U.S.C. $\$ 7408$ (a). See also Natural Res. Def. Council, Inc. v. Train, 545 F.2d 320, 328 (2d Cir. 1976).

300. See Jan. Notice, supra note 256, at 2; see also Citizens' Petition, supra note 246, at 9.

301. 42 U.S.C. $\$ 7411(b)(1)(A)$ (1995).

302. See generally Citizens' Petition, supra note 246. See also Food and Drug Admin. v. Brown \& Williamson Tobacco Corp., 529 U.S. 120, 159 (2000). .

303. 467 U.S. 837 (1984).

304. Chevron, 467 U.S. at 843 . Courts will defer to an agency's construction, so long as it is reasonable, and not "arbitrary, capricious or manifestly contrary to the statute." Id.

305. Brown \& Williamson, 529 U.S. at 159. 
agency from exercising significant policymaking authority in the area." ${ }^{306} \mathrm{~A}$ court may be swayed by the EPA's contention that any potential regulation of carbon dioxide would have "far greater economic and political implications than FDA's attempt to regulate tobacco," which the Supreme Court shot down in Brown \& Williamson. ${ }^{307}$

Yet, the EPA's lockstep application of Brown \& Williamson's holding to the context of carbon dioxide regulation has its detractors. ${ }^{308}$ Gary S. Guzy, former EPA general counsel under President Clinton, expressed skepticism about the relevance of Brown \& Williamson in his response to a May 2000 inquiry from Rep. David M. McIntosh (R-Ind.). ${ }^{309}$ Focusing on tobacco as an object of regulation, Guzy noted that Congress "persistently acted to preclude a meaningful role for any administrative agency in making policy on the subject of tobacco and health." 310 Guzy contrasted Congress' relationship with potential carbon dioxide regulation, noting, "Congress has not established any broad-based requirements specifically to address climate change, much less created a distinct alternative regulatory scheme for emissions of $\mathrm{CO}_{2}$. Nor has Congress acted to preclude administrative agencies from making policy on the topic of climate change."311

Guzy added that Congress' history of voting down carbon dioxide regulatory legislation does not dovetail with any holding in Brown \&

306. Id. at 159, 160. The Court announced, "we are confident that Congress could not have intended to delegate a decision of such economic and political significance to an agency in so cryptic a fashion." Id. at 160

307. § 202 Petition Denial, supra note 253 , at 52928. EPA added:

It is hard to imagine any issue in the environmental area having greater 'economic and political significance' than regulation of activities that might lead to global climate change. Virtually every sector of the U.S. economy is either directly or indirectly a source of GHG emissions, and the countries of the world are involved in scientific, technical, and political-level discussions about climate change.

Id.

308. See Brian Stempeck, Climate Change: States' Suit Against EPA Hinges on Supreme Court Tobacco Decision-Experts, GREENWIRE, Nov. 3, 2003.

309. See Memorandum from Gary S. Guzy, General Counsel, to Honorable David M. McIntosh, Chairman, Subcommittee on National Economic Growth, Natural Resources and Regulatory Affairs, Committee on Government Reform, U.S. House of Representatives (July 11,2000 ) (on file with author) [hereinafter Guzy Memorandum].

310. Id. at Question 1. Guzy quoted the Court's opinion in Brown \& Williamson, noting: Congress' tobacco-specific statutes have effectively ratified the FDA's long-held position that it lacks jurisdiction under the [Food, Drug and Cosmetics Act] to regulate tobacco products. Congress has created a distinct regulatory scheme to address the problem of tobacco and health, and that scheme, as presently constructed, precludes any role for the FDA.

Id.

311. Id. He added, "To the contrary, with Congressional authorization and appropriations, EPA has been working intensively on climate change issues for many years now, in areas such as international negotiations, policy evaluation, scientific and economic research, and establishing voluntary programs to reduce greenhouse gas emissions ...." Id. 
Williamson to preclude the EPA from affirmatively acting to regulate carbon dioxide. ${ }^{312}$ He observed that "the Court [in Brown \& Williamson] explicitly disavows as a basis for its decision Congress' rejection of legislation that would have explicitly [given] FDA authority to regulate tobacco as customarily marketed." ${ }^{\prime 313}$ As a result, he posited that

the Brown \& Williamson decision does not undermine, and arguably implicitly supports, the view that failure to enact a statutory provision specifically directed at climate change has no effect on general CAA provisions authorizing EPA to identify and regulate any air pollutants meeting the statutory criteria relating to endangerment of health or welfare. ${ }^{314}$

Nonetheless, the D.C. Circuit's ruling in Train provides the states a stronger likelihood to succeed on their criteria pollutant challenge. ${ }^{315}$ However, the states' case rests on their ability to convince a court that global warming meets the Ethyl Corp. v. EPA "demonstrable harm" requirement ${ }^{316}$ and is an actual threat to public health or welfare. ${ }^{317}$ To succeed, the states must present evidence in support of their public health and welfare claims that will overcome the EPA's likely retort-that the science of global warming impacts is inconclusive and more study is required before regulations are warranted. ${ }^{318}$ As one set of commentators suggests, this is not an insurmountable goal. ${ }^{319}$ The commentators note, "[c]urrent scientific findings, though uncertain, suggest some degree of human interference with the

312. Id. at Question 3.

313. Guzy Memorandum, supra note 309, at Question 3. He quoted the Court's reasoning that, "We do not rely on Congress' failure to act-its consideration and rejection of bills that would have given the FDA this authority-in reaching [the] conclusion [that the 'actions by Congress over the past 35 years preclude an interpretation of the FDCA that grants the FDA jurisdiction to regulation tobacco products." Id. He added, "The Court instead focuses on Congress' affirmative actions in enacting several statutes 'creating a distinct regulatory scheme for cigarettes and smokeless tobacco." Id.

314. Id.

315. See Natural Res. Def. Council, Inc. v. Train, 545 F.2d 320, 328 (2d Cir. 1976).

316. See Ethyl Corp. v. EPA, 541 F.2d 1, 15 (D.C. Cir. 1976).

317. Id.

318. See id. See also $\$ 202$ Petition Denial, supra note 253, at 52931. Even with respect to the $\S 108$ challenge, EPA is likely to stand by its argument that, "[u]ntil more is understood about the causes, extent and significance of climate change and the potential options for addressing it, EPA believes it is inappropriate to regulate GHG emissions." Id.

319. See Bugnion \& Reiner, supra note 13, at 503. The authors recognized that " $t \mathrm{t}] \mathrm{he}$ statutory language also suggests that the [Clean Air Act] does not require EPA to know the precise health and welfare effects that a pollutant causes in order to justify adding that pollutant to the list." Id. at 504. They pointed to the court's holding in Ethyl Corp., which "acknowledged that some of the questions involved in the promulgation of environmental regulations are 'on the frontiers of scientific knowledge' and therefore require decisions based more on judgment than "purely factual analyses." Id. 
climate," and that the result under Ethyl Corp. "would support the regulation of greenhouse gases as a policy decision if, in EPA's judgment, human interference translates into endangerment." 320

\section{A COMPARISON BETWEEN PREDICTED U.S. RESULTS UNDER THE KYOTO PROTOCOL AND UNDER FORCED REGULATION PURSUANT TO THE NORTHEAST STATES' LAWSUITS}

Conditions in the United States-both atmospheric and sociopolitical-could assume a range of forms, depending on the regulatory system instituted to address carbon dioxide emissions reductions. In coming years Congress could end its standstill and enact a statutory gridwork to stabilize and cut carbon dioxide volumes. That gridwork could include a cap and trade system, such as the one at the heart of the 2003 McCain-Lieberman legislation, or some other regulatory mechanism yet to be crafted. ${ }^{321}$ On the other hand, the legislative impasse could continue and the United States could remain uncommitted to any course of action. ${ }^{322}$

Congress was unable to break through the impasse when it considered enabling legislation to address the problem of atmospheric lead pollution. ${ }^{323}$ The EPA in turn declined the opportunity to promulgate NAAQS for lead, and proponents turned to the courts. ${ }^{324}$ Some commentators suggest that regulation of carbon dioxide under the NAAQS may not achieve success the way lead NAAQS arguably have in the wake of NRDC $v$. Train. ${ }^{325}$ As regulation under Section 202 requires the same threshold requirements as Section 108, any impediments to regulation would arise under either

320. Id. The authors added, "For climate change, the scientific evidence, albeit contested, supports a finding that action should be taken." Id. Despite the scientific dispute, "the precautionary mandate of the [Clean Air Act] has been consistently upheld, and contradictory claims, many of which have not been peer reviewed, should not affect the deference that courts grant to agency judgments based on scientific findings." Id.

321. See generally McCain-Lieberman Debate, supra note 197.

322. See id. at $\$ 13487$.

323. See Natural Res. Def. Council, Inc. v. Train, 411 F. Supp. 864, 867 (S.D.N.Y. 1976).

324. See id.

325. See Denee A. Diluigi, Kyoto's So-Called "Fatal Flaws": A Potential Springboard for Domestic Greenhouse Gas Regulation, 32 GolDEN GATE U. L. REV. 693, 725 (2002). The author recognized that the scientific community closely linked lead exposure to seizures, mental retardation and behavioral disorders, and could be easily tied to lead content in gasoline. See id. at 747. With carbon dioxide, "the ability to regulate . . . is debatable." Id. at 726 . "The limiting factor . . . is the 'reasonably endanger' factor, which is ultimately at the discretion of the regulating agency." Id. at 725-26. "[T] he specific scientific data to convince the EPA that GHGs reasonably endanger public health or welfare may not be available. The connection between the data and environmental impacts is likely too attenuated to warrant GHG regulation under NAAQS." Id. at 726. 
mechanism. ${ }^{326}$ As discussed, these considerations will likely be left to a federal court to decide. ${ }^{327}$

With this in mind, prudence suggests that stakeholders might ask how regulation under the domestic program would look if a court rules in favor of the petitioners. Would the rules feature workable guidelines, through which regulators and polluters could achieve tangible carbon dioxide emissions reductions? Moreover, how would the results of such regulation compare with the hypothetical reductions which would result if the United States ratified the Kyoto Protocol?

The United States' commitment under the Protocol is to reduce its 1990 carbon dioxide emissions levels by seven percent by $2010,{ }^{328}$ In 1990 the United States' total greenhouse gas emissions were 6,038.2 teragrams of carbon dioxide equivalents $\left(\mathrm{Tg} \mathrm{CO}_{2}\right.$ Eq.), ${ }^{329}$ of which, carbon dioxide comprised eighty-one percent. ${ }^{330}$ Under its Protocol commitment, the United States would have to reduce it total GHG emissions by $422.7 \mathrm{Tg} \mathrm{CO}$ Eq. below its 1990 figure by $2010 .^{331}$ Yet, the United States' aggregate GHG emissions increased between 1990 and 1999 by eleven percent, ${ }^{332}$ with carbon dioxide emissions increasing by 13.1 percent. ${ }^{333}$ These figures neglect the use of sinks, ${ }^{334}$ which accounted for $990.4 \mathrm{Tg} \mathrm{CO}_{2} \mathrm{Eq}$. in 1999 , but this neglect has little effect on any reductions the United States would have to undertake because reported sinks actually dropped between 1990 and 1999. ${ }^{335}$ Therefore, using 1999 figures, the United States would have to reduce its total

326. See 42 U.S.C. $\$ 7521$.

327. See $\S 108$ Appeal, supra note 247. See also $\$ 202$ Appeal, supra note 247.

328. See Guide, supra note 45, at 22.

329. Climate Action Report, supra note 262, at 29. In its periodic reports to the COP, the United States presents "global warming potential-weighted emissions of all direct greenhouse gases ... in terms of equivalent emissions of carbon dioxide" using the measure of $\mathrm{Tg} \mathrm{CO}_{2} \mathrm{Eq}$. Id. at 27. One teragram equals one million metric tons (106 metric tons), which equals 109 kilograms. See id.

330. Id. at 29. This represents $4,913.0 \mathrm{Tg} \mathrm{CO}$ Eq. More than ninety-eight percent of all carbon dioxide emissions in 1990 was derived from fossil fuel consumption, totaling $4,835.7$ $\mathrm{Tg} \mathrm{CO} 2$ Eq. See id. Cement manufacture, waste combustion, lime manufacture, natural gas flaring, limestone and dolomite use, soda ash manufacture and consumption, and carbon dioxide combustion account for the remaining emissions included in the total. See id. Methane, nitrous oxides, hydrofluorocarbons, perfluorocarbons, and sulfur hexafluoride account for the remainder of total GHGs reported. See Climate Action Report supra note 262, at 29.

331. See id.

332. $707.9 \mathrm{Tg} \mathrm{CO}$ Eq.

333. Id. This represents $645.1 \mathrm{Tg} \mathrm{CO}$ Eq. Total United States GHG emissions topped out at $6,746.0 \mathrm{Tg} \mathrm{CO} 2 \mathrm{Eq}$. in 1999 , more than eighty-two percent of which was carbon dioxide.(5,558.1 $\mathrm{Tg} \mathrm{CO}$ Eq.). Id.

334. The term "sink" refers to any practice or physical phenomenon, such as a change in land-use or a forest, that absorbs carbon dioxide. See generally id.

335. Id. The United States reported 1,059.9 $\mathrm{Tg} \mathrm{CO}_{2}$ Eq. in 1990. Id. 
GHG emissions by nearly seventeen percent ${ }^{336}$ before 2010 to meet its Protocol target. ${ }^{337}$

Quantifying predicted results under Section 108 and Section 202 regulation, however, presents a greater challenge because the EPA would first need to resolve lingering questions about climate change science. ${ }^{338}$ First, the agency would be required to establish firm findings as to the limits, comparable to those effected for other pollutants, at which carbon dioxide "cause[s] or contribute[s] to air pollution which may reasonably be anticipated to endanger public health or welfare."339 Criteria pollutant NAAQS require decisive action, where the EPA sets limits measured in acute terms, generally equivalent to parts per million, or p.p.m. ${ }^{340}$ The EPA would be required to establish comparable air quality standards for carbon dioxide, pursuant to Section 109,341 "based on such criteria . . . requisite to protect the public health" and "requisite to protect the public welfare from any known or anticipated adverse effects associated with the presence of air pollutants in the ambient air." $" 342$

To accomplish this goal, the states in turn would bear the burden of targeting primary carbon dioxide emission sources-power plants, motor vehicles, and land use changes. States bear discretion in crafting their SIPs to attain their air quality standards. ${ }^{343}$ States may do so through imposition of hard emissions caps on individual sources alone, or combined with use of one or more tools comparable to the flexibility mechanisms the Protocol provides. ${ }^{344}$ If the EPA sets NAAQS for carbon dioxide, they may coincide with QELROs, applied by the Protocol, if the EPA's public health and welfare determinations coincide with the reduction targets approved by COP ${ }^{345}$

\section{6. $1,130 \mathrm{Tg} \mathrm{CO}_{2}$ Eq.}

337. See Climate Action Report, supra note 262, at 29.

338. See Bugnion and Reiner, supra note 13, at 504-06.

339. 42 U.S.C. $§ 7408(a)(1)(A)$.

340. See, e.g., National Primary and Secondary Ambient Air Quality Standards for Carbon Monoxide, 40 C.F.R. $\$ 50.8$ (2003). EPA set the current NAAQS for carbon monoxide as " 9 [ppm] $(10[\mathrm{mg} / \mathrm{m} 3])$ for an 8-hour average concentration not to be exceeded more than once per year and (2) 35 [ppm] $(40[\mathrm{mg} / \mathrm{m} 3])$ for a 1-hour average concentration not to be exceeded more than once per year." Id. See also, National Primary and Secondary Ambient Air Quality Standards for Lead, 40 C.F.R. $§ 50.12$ (2003). "National primary and secondary ambient air quality standards for lead and its compounds, measured as elemental lead by a reference method based on appendix $G$ to this part, or by an equivalent method, are: 1.5 micrograms per cubic meter, maximum arithmetic mean over a calendar year." $I d$. 1.5 microgram per cubic meter (mg/m3) equals .015 p.p.m. See Technical Information, Conversion Table, available at http://www.spexcsp.com/crmmain/technical/convers.htm (last visited Mar. 29, 2004).

341. 42 U.S.C. $\$ 7409$ (a)(2).

342. 42 U.S.C. $\$ 7409$ (b)(1), (2).

343. See 42 U.S.C. $\$ 7410$

344. See generally Protocol, supra note 5.

345. See Breidenich, Magraw, Rowley \& Rubin, supra note 81, at 319. For example, EPA may determine that public health concerns require primary NAAQS for carbon dioxide to be set at a level that coincides with the seven percent reduction from 1990 levels, which the Protocol 
Some key differences between Kyoto compliance and institution of a domestic emissions reduction program stand out. For instance, a domestic program would likely not include the international emissions trading mechanism, which would be central to the United States ability to comply with the treaty. ${ }^{346}$ With no domestic political squabbles around negotiations with foreign powers, the EPA could implement a court-ordered emissions reduction program more easily than it could amidst congressional sparring over questions of international diplomacy. ${ }^{347}$

The Protocol does not stipulate the means through which Parties must attain their QELROs, but reduction of motor vehicle emissions would be necessary to any meaningful carbon dioxide reduction project enacted in the United States. ${ }^{348}$ Section 202 presents a different set of variables, but their application would likely reach a similar result to that attained under carbon dioxide NAAQS. ${ }^{349}$ The idea of reducing atmospheric carbon dioxide volumes by targeting motor vehicle emissions is neither new nor novel. ${ }^{350} \mathrm{By}$ adapting automobiles to run on hydrogen fuel cells, solar power, or carbon fuels from biomass sources, manufacturers could drastically reduce carbon dioxide emissions released into the atmosphere. ${ }^{351}$ However, scientists believe that significant reductions can be attained merely by improving the gas mileage of the standard internal combustion engine. ${ }^{352}$ The National Academy of Sciences released a study in 1991, which proposed that "mileage standards should rise to about 48 miles per gallon (m.p.g.) for private vehicles and 40 m.p.g. for heavy trucks." 353 Yet, studies indicate that society must do more than improve fuel economy of existing form internal combustion engines if it expects to undertake meaningful reductions in atmospheric carbon dioxide

assigns to the U.S., or requiring a reduction in carbon dioxide emission to $5,615.54 \mathrm{Tg} \mathrm{CO} \mathrm{Cq}_{2}$. See id.

346. See Protocol, supra note 5, at 40.

347. See Peter J. Wilcoxen, What's Wrong With the Kyoto Protocol? There is a Better Policy for Addressing Global Climate Change, in GLOBAL WARMING AND THE KYOTO ACCORD: WHAT IS TO BE DONE? 79, 83 (David J. Eaton, ed., 2001). Wilcoxen notes that the international trading regime, while "well intended," would force the United States to "buy a lot of permits from elsewhere," likely "China or Russia." Id. "So, now the Senate would likely raise the issue that we might be sending large chunks of wealth to controversial countries." Id.

348. See JOHANSEN, supra note 21, at 263.

349. See 42 U.S.C. $\$ 7521$.

350. See JOHANSEN, supra note 21, at 263.

351. See id. DiamlerChrysler has been working on an experimental car called the NECAR4, which would run on a hydrogen fuel cell, "emitting only water vapor from its exhaust pipe. Id. The car, modeled on a Mercedes sedan, with room for five people and their luggage, would expend less than 20 percent of the energy used by a typical "economy car." Id.

352. See id.

353. Id. The Sierra Club recommends that the government impose gas mileage standards of 45 m.p.g. for cars and 34 m.p.g. for light trucks, and states that such standards would be "the biggest single step the U.S. can take to curb global warming and reduce our dependence on oil. JOHANSEN, supra note 21, at 264. 
levels. ${ }^{354}$ Because the number of cars used worldwide is increasing, the sheer number of new mobile sources contributing to global atmospheric carbon dioxide volumes would offset any reductions exacted by improved gas mileage. ${ }^{355}$ To achieve meaningful reduction or stabilization of GHGs, "fundamental changes in transportation technology will be required." 356

\section{CONCLUSION}

The near future may vindicate President Bush for presciently predicting the death of the Kyoto Protocol. ${ }^{357}$ Without ratification by either Russia or the United States, the treaty will fall short of the threshold set for it to take effect. ${ }^{358}$ Nonetheless, pressure from courts as well as community leaders leaves government little opportunity to continue its avoidance of the global warming phenomenon as time goes by. ${ }^{359}$

Government and community stakeholders have begun to adjust their operations because of global climate change in spite of inaction by the federal government. In October 2002, a Connecticut task force outlined a strategy for undertaking near and long term solutions to climate change problems within that state. ${ }^{360}$ One author connected with the task force recognized that, while local decisions can impact the problem, American society must alter its thinking 4 before meaningful GHG reductions are achieved:

The only way to reduce greenhouse gases and other pollution while achieving expected economic growth is to bring about a wholesale transformation in the technologies that dominate manufacturing, energy, transportation, and agriculture. We must rapidly abandon the 20th century technologies that have contributed so abundantly to today's problems and replace them with 21 st century technologies designed with environmental sustainability in mind. ${ }^{361}$

354. Id. at 264-65.

355. Id. at 265. The author notes that the "world fleet or automobiles and light trucks was 53 million in 1950 and 400 million by 1990 ," and that "[a]nnual production was 10 million in 1950 and 50 million in 1990." Id.

356. Id.

357. See Shillinger, supra note 8.

358. See Glasser, supra note 8.

359. See $\$ 108$ Appeal, supra note 247. See also $§ 202$ Appeal, supra note 247. See also Leading By Example: Connecticut Collaborates to Reduce Greenhouse Gas Emissions, Pocantico Paper No. 6, The Pocantico Conference Center of the Rockerfeller Brothers Fund, Oct. 4, 2002, available at http://www.rbf.org/pdf/leading\%20by\%20example.pdf (last visited Mar. 29, 2004).

360. Id. at 5 .

361. Id. at 7. 
The means of achieving that change in public thinking need not include ratification of the Kyoto Protocol. Failure to ratify may damage the United States' bargaining position in world politics and generally undermine the integrity of international environmental protection. However, the United States may still take meaningful steps toward mitigating the effects of global warming without accepting the Protocol's limitations.

A court may order the EPA to institute such a mechanism, but either the agency or Congress can avoid such a mandate by taking affirmative steps to regulate carbon dioxide emissions. If the EPA re-acknowledges carbon dioxide's status as an air pollutant, thereby repudiating the Fabricant Memorandum, the agency could regulate the gas under one or more sections of the Clean Air Act. ${ }^{362}$ Moreover, Congress could enact new enabling legislation, such as that proposed in the Climate Stewardship Act of 2003, ${ }^{363}$ which would provide the EPA with an unequivocal foundation to work upon the mitigation of global warming effects. ${ }^{364}$

Scientists have come to predict harmful consequences of global warming with increasing regularity and with a decreasing amount of dissent. ${ }^{365}$ If society seeks to avoid those consequences yet maintain its skepticism about adhering to the international framework, it bears no other option than establishment of a domestic mechanism that will reduce atmospheric carbon dioxide levels. 
